Yayınlayan: Ankara Üniversitesi KASAUM

Adres: Kadın Sorunları Araştırma ve Uygulama Merkezi, Cebeci 06590 Ankara

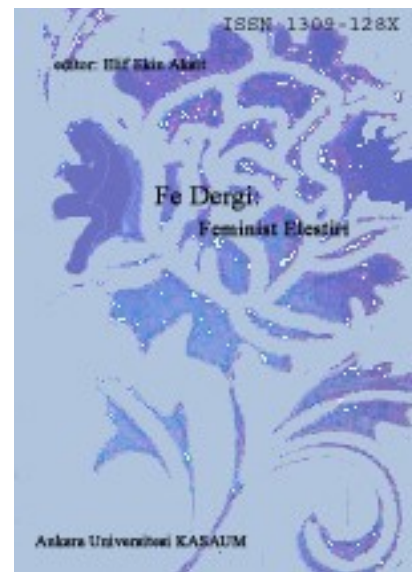

Fe Dergi: Feminist Eleștiri 4, Sayı 2

Erişim bilgileri, makale sunumu ve ayrıntılar için:

http://cins.ankara.edu.tr/

Gizem ya da sapkınılk: Türkiye'de 1930-60 Yılları

arasında seksoloji söylemi

Aslı Yazıcı Yakın

Çevrimiçi yayına başlama tarihi: 28 Aralık 2012

Bu makaleyi alıntılamak için: Aslı Yazıcı Yakın, "Gizem ya da sapkınlık: Türkiye'de 1930-60 Yılları Arasında seksoloji söylemi ” Fe Dergi 4, sayı 2 (2012), 87-xx.

URL: http://cins.ankara.edu.tr/8_8.html

$\mathrm{Bu}$ eser akademik faaliyetlerde ve referans verilerek kullanılabilir. Hiçbir şekilde izin alınmaksızın çoğaltılamaz. 


\section{Gizem ya da Sapkınlık: Türkiye’de 1930-60 Yılları Arasında Seksoloji Söylemi Aslı Yazıcı Yakın*}

Türkiye'de 1930-60 yılları arasında kadınlara hitap eden başlıklarlyla cinsi ve cinsî terbiyeye yönelik bir dizi metin yayımlandı. Kadınlara, erkeklerle nasıl konuşulacă̆ını, bedenlerini nasıl terbiye etmeleri gerektiğini ve toplum içindeki uygun davranışlarl öğretmeye talip olan bu dergi ve kitaplar doğa-kültür, beden-zihin gibi kavramsal ayrımlarla hizalanan yerleşik bir akıl yürütmeden ve on dokuzuncu yüzyılın ikinci yarısında Avrupa'da gelişen popüler seksoloji söyleminden beslendiler. Tüm bu metinlerde kadın bir dizi akıl yürütme ile aşamalı bir biçimde görünmez kılınır. Metinlerin kurgusuna göre kadının yeri evdir ve onu görünür kılan da sadece evde yapması gereken işler ve kocanın bakımıdır. Öte yandan görünmezlik de kadına gizem ve erdem olarak sunulur. Gizem ve erdem kadının tek hareket alanı olarak kalan bedenini de istila eder ve cinsellikten alınacak haz da fazilet ve sapkınlık gibi iki uçta tanımlanır.

Anahtar Kelimeler: Gizem, gizlilik, erdem, tutumluluk, seksoloji

\section{Mystery or Deviance: Sexology Discourse in Turkey Between 1930-60}

Between the years 1930-60, a series of books and magazines on sexual education were published that exclusively aimed at women in Turkey. Those texts, intended to teach women how to talk to men, how to discipline their bodies and minds, were fed from the situated reasoning which was being formed by aligned concepts such as nature-culture and body-mind and the popular sexology discourse which emerged in Europe during the nineteenth century. According to these texts a woman's place is her home and a number of duties including the care of the husband make her merely visible. The invisibility on the other hand is presented to woman as something being mysterious and virtuous. Mystery and virtue invade woman's body which is the only place remained for her to move around and the pleasure of sex would be defined in opposite ends like virtue and deviance.

Key Words: Secrecy, mystery, virtue, economy, sexology

Giriş

Çok fena huylu olduğunu anladığınız bir adamla bile gayet güzel uyuşmak kabildir. Onun fena bir adam olduğunu ve size nasıl mukabele edeceğini her zaman aklınızda tutarsanız mesele kalmayacaktır. Siz istemedikten sonra kimse sizinle kavga edemez. Elverir ki siz karşınızdaki kimsenin kavgacı olduğunu biliniz ve ona uymamağa karar vermiş olunuz. O zaman göreceksiniz o bir söylenecek, iki söylenecek, sizden mukabele göremeyince yaptığı kavgada bir tat, tuz bulamayacak ve nihayet susup oturacaktır."

Kadınlara erkeklerle anlaşma yollarını anlatan yukarıdaki paragraf Hayatta Muvaffak Olmak Için Bir Kadının Bileceği Şeyler adlı kitaptan alınmıştır. Türkiye'de 1930-60 yılları arasında Kadınlık Sanatı ${ }^{2}$, Annelere ve Genç Kızlara Öğ̈ütler ${ }^{3}$, Evli Kadınlar Iç̧in Metres Tehlikesi ${ }^{4}$, Genç Kızlara Göre İzdivaç ve Zifaf ${ }^{5}$, Dişi Kuş: Kocanızı Nasıl Muhafaza Edebilirsiniz ${ }^{6}$ isimleriyle bir dizi kitap yayımlandı. Bu çalışmada telif ve İngilizce ve Almanca'dan çeviri olan bu kitaplardan bazıları ve 1949 yılında yayımlanmaya başlanan Seksoloji: Cinsi Bilgiler Mecmuası ele alınmaktadır. Telif kitaplar arasında müstear isimle yazılanlar, çeviri metinlerde yanlış yazılmış isimler ve varlığı şüpheli yazar adları yer alır. Çevirilerde kimi zaman Hıristiyanlığın kadına, aileye verdiği değeri anlatan bölümler çıkarılmış, yerine benzer biçimde ama bu defa Müslümanlığın kadını nasıl yücelttiğini anlatan ifadeler eklenmiş, kimi zaman da kitabın girişinde bir grup yazar adı sıralanarak bu yazarların eserlerinden derleme yapıldığı belirtilmiştir. Metinlerin çoğu cinsellik, psikoloji ve patoloji söylemi

*Doç. Dr., Antropoloji Bölümü, Ankara Üniversitesi. 
içinden konuşan tıp doktorlarına ve psikiyatrlara aittir. Çevirilerde, çıkarılmış, eklenmiş bölümler ya da yanlışlıklar üzerinde durulmamıştır.

Bu metinleri besleyen iki kaynak vardır: Kadın ve erkeğe dair doğa-kültür, beden-zihin gibi ayrımları izleyerek hizalanmış arkaik ikili kavramlaştırmalar ve ardından daha geniş bir modernleşme ve pozitivistik bir epistemoloji bağlamından türeyerek On Dokuzuncu yüzyılda Avrupa'da beliren seksoloji söylemi. Bu kitaplar cinsel sağlık, cinsel yaşam, kadın erkek ilişkileri ve evlilik konularında bilgi ve ögütler verirken, arka planda birbiri ile ilişkili bir dizi olay üzerinden kadının yaşamını hikâye ederler. Bu hikâyenin olay örgüsü içerisinde genç kızlık, zifaf gecesi evlilik, çocuk yapmak, evde ve ev dışında erkeklerle geçinmeyi öğrenmek gibi aşamalar kaçınılmaz olarak ve kronolojik biçimde yer alır. Bu bağlamda metinlerin geneline hâkim ve kadının davranışlarını yönlendirmeyi hedefleyen ve tutumluluk teması üzerinden gelişen bir anlatısallık söz konusudur. Kitaplar bu anlatısallık üzerinden okunmuştur. Tutumluluk, metinlerde doğrudan dillendirilmez ancak cinsel haz, konuşma ve davranışları dâhil olmak üzere kadınlardan her alanda ölçülü olması istenir, ölçülülük de erdem olarak sunulur. Metinlere göre kadın bedenine iyi bakmalı, kocasına fazla teşhir etmemeli, cinselliği ölçülü yaşamalı ve alacağı hazzı kontrol edebilmeli, az ve zamanında konuşmayı ve erkeğin anlattıklarını dinlemeyi bilmelidir. Bedenini, cinselliğini, dilini, makul sayılan sınırlar dışında kullanacak kadınları, tıbbi açıklamalarla desteklenen hastalık ve felaketler beklemektedir. Evliliğe ilişkin önerilerin yer aldığı ve cinsel yaşama ait bilgi ve öğütler veren bu kitaplar, bir yandan cinsellik üzerinden, diğer yandan da evin temizliği, yemeklerin güzelliği ya da kadının evde ve ev dışında davranışları ile kocayı memnun etme yollarını anlattıkları için birbirlerini tamamlayan tek bir söylemsel alanı oluştururlar. Seksoloji de yalnızca cinsel sağlık ve cinsel ilişkiden söz eden bir bilim alanı ya da tıp biliminin bir alt dalı değil, cinsellik, hukuk, ahlak, tıp, iktisat, din gibi gündelik yaşamın içinde doğrudan deneyimlenen, antik dünyanın seks kılavuzlarından beslenen ve birbirinin içinden geçen alanlarda kendini gösteren bir söylem olarak var olur.

\section{Aşk Sanatından Seks Bilimine}

Cinsel sağlık, sevişme teknikleri, kadın erkek ilişkileri ve evlilikten söz eden kitaplar bir anda ortaya çıkmadılar. Antik Yunan, Hint, Arap dünyasında, Osmanlı ve Ortaçağ Avrupa'sında cinsel davranışı düzenlemeye yönelik, betimleyici, sınıflandıran ve kadın erkek ilişkilerini hizalayıcı kavramlar üzerinden kurgulayan çok sayıda metin vardır. M.Ö 4-6 yüzyıllar arasında yaşadığı tahmin edilen Hintli filozof Vātsyāyana'nın metni Kama Sutra erdem, refah ve aşk üzerine düşüncelerle açılır ve ardından şarkı söylemek, dans etmek, şiir yazabilmek, resim, takı yapabilmek gibi farklı alanlarda beceri elde etmenin önemini vurgular. İnsanların festival ve pikniklerde nasıl davranması gerektiği, başka erkeklere ait kadınlarla ilişki kurma, hangi tür kadınlarla evlenilebileceği, güven duygusu yaratma ve kadının düşüncelerini okuma, sevişme sırasında yapılacaklar ve erdemli bir kadın olmanın yolları gibi konular kitap içerisinde detaylı biçimde anlatılır. Ovid'in M.S. 2'de Roma'da yazdığı da $A s ̧ k$ $S_{a n a t ı}{ }^{8}$ kadınlara ve erkeklere ögüutlerle doludur. Çok sayıda insanın bir performansı izlediği sirk, tiyatro, arena gibi yerler bir aşkın başlangıcı için idealdir. Seçilen kadını izlemek ve verdiği tepkilerin benzerini vermek önemlidir. Ovid, ele geçirilemeyecek kadın olmadığını ileri sürerken, başlangıç için güzel sanatlardan anlamanın önemini vurgular. Ancak erkek de kendisine bakmalı, dişini, tırnağını temiz tutmalı, burnundan çıkan kılları almalı ve ayaklarından taşan büyük ayakkabılar giymemelidir. Kadına özellikle giysileri ve görünüşü ile ilgili bol iltifat etmek, yaşını sormamak, eğitici tavrı ile konuşmamak, ayıkken söylenemeyecek şeylerden dolayı özür dilemek durumunda kalmamak için biraz sarhoş taklidi yapmak gerekecektir. Buluşmaların arasını belli sürelerde tutarak kendini merak ettirmek ama bu süreleri uzun tutmamak da önemlidir. Ancak parası olan bir erkeğin aşk sanatını öğrenmesine ihtiyacı da yoktur. Kadının kaprislerine katlanmak, hasta olduğunda şefkat göstermek önemlidir ama hastalığını iyileştirecek önerilerde bulunmayı rakiplere bırakmak akıllıcadır. Metnin kadınlara yönelik bölümünde ise bir kadının nasıl gülmesi, ağlaması, konuşması, yürümesi gerektiği, güzel bakışların önemi vurgulanır ve uygun saç, ayakkabı, seçimleri anlatılır. Kadınlar için sade giyim, hafif makyaj ama erkeğin makyaj yapıldığına tanık olmaması, tüysüz bacaklar, temiz dişler, kokmayan koltukaltı Ovid'in, öğ̈̈tleri arasındadır. On Beşinci yüzyıldan kalma bir metin olan Kokulu Bahçe ${ }^{9}$ Şeyh Muhammed El Nefzavi'ye aittir. Burada da hangi kadın ve erkeklerin karşı cinse daha cazip geldiği, kadınların nasıl hilekâr ve aldatıcı olabildikleri, sevişme teknikleri ve cinsel sağlık ile ilgili bilgiler yer alır. Metin içinde erkeklerin hoşlandığı güzel kadın hem fiziksel özellikleriyle tanımlanır hem de az konuşup az gülmesi gerektiği, eşine dostuna gitmek için bile evden ayrılmamasının önemi vurgulanır ${ }^{10}$. Cinsel konulardan söz eden kitaplar yani bahnameler Osmanlı'da da yazılmıştır. Bardakçı1 ${ }^{11}$, İbni Sina'dan, Nasreddin-i Tusi'ye dek çok sayıda bilginin bahname kaleme aldığını ve zaman içinde bu metinlerin içeriklerinde değişiklikler olduğunu belirtir. İlk dönem 
bahnamelerinde dönemin tıp bilgilerine de yer verilmiş, cinsel gücü ve isteği arttırma yollarından söz edilmiştir. Bardakçı, bu kitapların genellikle cinsel konularda sorunlar yaşayan sultanların isteği ile yazıldığını ya da sultanın cinsel hazzını artırmayı kendine görev bilen bir yazarın girişimi olduğunu söyler. Bu metinler erkeklere hitap eder ve kadınlar da cinsel ilişki sırasında erkeğe zevk veren araçlardır. Zamanla bahnamelerden bu bilgiler kalkmış, cinsel sağlıkla ilgili konular dönemin hekimleri tarafından kaleme alınırken, bahnameler ağırlıklı olarak farklı sevişme tekniklerinden söz eden metinlere dönüşmüştür.

On dokuzuncu yüzyıla gelindiğinde Avrupa'da seksoloji adı ile bilimsel bir dil oluşur. Cinsellik deneyimleri, cinsel davranışın patolojik boyutları, cinsel davranış ve kimliklerin tanımlanıp sınıflandırılması, kadınların ve erkeklerin yaradılıştan sahip olduklarına inanılan arzular, cinsel fizyoloji, anatomi ve evlilik üzerine yazılan kitaplar, öjeniden sınıf kavramına kadar birçok eksen üzerinden ilerler ve cinsellik, biyoloji, tıp ve psikiyatrinin açıklamalarıyla bilimsel bir uzam olarak kurulur. Foucault, bu yeni alanın tehlikeli addedilen cinselliğe karşı bir mücadele, itaatkâr olmayanı baskılama yöntemi ya da yararlı bir cinsel bilgi sunma çabası olmaktan çok "cinselliğin kendisinin üretimi"" 12 olduğunu söyleyecektir ama bu saptama her dönem için yapılabileceğinden tek başına bir şey ifade etmez. On sekizinci yüzyılla birlikte hukuksal ve ahlaksal sapkınlığın yanına bir de seksoloji ile tanımlanan sapkınlığın eklenerek cinselliğin farklı kurumlar içinden kamusal ve yararlı söylemlerle düzenlenmek istendiği Foucault'nun temel vurgusudur. Yasalar cinsellik suçları karşısında daha az sıkı hale gelmiştir ancak adalet yerini tıbba ve eğitbilime bırakarak cinsellik gizlenir olmuştur. Bu süreçte cinselliği, cinsellik hakkında çokça konuşarak gizlemek için yeni edep kuralları çıkar ve gençlerin cinsel etkinlikleri okul ve aile aracılığı ile denetim altına alınır. Sinir hastalıkları, aşırılık, sapma ve üremeye ilişkin sorunlar cinsellik söylemine dâhil edilerek sinıflanır, alışılagelmiş birer günah addedilmekten çıkarak tuhaf doğalar olarak sağlık teknolojileri ve patolojinin alanına sokularak tıbbileştirilir. Foucault, cinselliğin On Sekizinci yüzyıla kadar evlilik, akrabalığın sabitleşmesi, isim ve malların sürekliliği gibi konularla sınırlı olduğunu düşünür. Ancak antik dünyanın cinsellik deneyimlerinin Foucault'nun saptadığı bu düzenlemeler ve söylemlerin aynısı ile denetlenmiyor oluşu bu alanın boş bırakıldığı ve dönemin tıp anlayışı ile gündelik yaşamın içine sinmiş cinsel pratikler bütünü olmadığı manasına gelmez. Ağırlıklı olarak antik dünyaya ait olduğu ileri sürülen ve erotik sanat olarak adlandırılan pratikler bütünü de reçeteler, teknikler ve sınıflandırma biçimleri üzerinden tıbbileştirilmiş bir cinsellik uzamını yaratmıştır. Üretkenlik, yararlılık ve ölçülebilirlik, fayda, zarar, cinsel hazzı artırmaya yönelik reçete, teknik ve formüller, beden tiplerine göre sınıflandırmalar bu metinlerde de yer alırlar. Foucault'ya göre Çin, Japonya, Hindistan, Roma, Arap Müslüman toplumları erotik sanat yaratmıştır ancak çözümlemesi boyunca Çin, Hindistan ya da Arap ve Müslüman toplumlarının seks metinleri üzerinden bu bağlamda yapılmış bir okumaya da rastlanmaz. Ayrıca eski metinlerle yeni seksoloji dili arasında erkek ve kadının hiyerarşik konumlanması açısından derin farklar yoktur. Bahnamelerin bazıları kadın ve erkek cinsel organlarını, fiziksel özelliklerine göre ayırarak anlattıkları gibi, farklı ülkelerin kadınlarını da fiziksel özellikleri, karakterleri ve cinsellikten aldıkları haz üzerinden ayırarak betimlerler ve erotik sanat adı altında geçen metinlerin büyük çoğunluğu erkeklere, erkeklerin deneyimleri ve arzuları üzerinden ve erkek diliyle yazılmıştır. Öte yandan Foucault, On Sekizinci yüzyıl ile birlikte gelişen seks biliminin itaatkâr olmayanı baskılama yöntemi olmadığ 1 düşüncesindedir ancak seksolojinin, abartılı ve sapkın cinsel pratiklere olan merakını da ahlak ile ve doğruyu söyleme adına korku üretmekle ${ }^{13}$ bağlar. Bu iki ifade bir yandan kendi içinde çelişir bir yandan da cinsel pratiklere dair çoğalan söylemlerin ve cinsellikle ilgili uygunluk kurallarının kadın açısından sonuçlarını, korkutulanın kadın olduğunu görmezden gelir. Seksolojinin kullandığı dil, özellikle hukuk ve tıp olmak üzere insan yaşamı için çok temel olan iki konuyu keser ve gündelik pratikler içerisine kolaylıkla sızabilme gücünü de buradan alır. Seksoloji söylemi bu bağlamda kendisinden önce yazılmış çok sayıda metinle alışveriş halindedir. Bakhtin'in ifadesiyle söylemek gerekirse, olası bütün metinlerden çok daha fazla dialojik/söyleşimseldir.

Richard von Kraft-Ebbing ve Havelock Ellis, Foucault'nun, "bedenin histerikleştirilmesi, hazzın psikiyatrikleştirilmesi, çocuk cinselliğinin eğitimbilimselleştirilmesi ve üretkenliğe ilişkin davranışların toplumsallaştırılması" "14 başlıklarında özetlediği cinselliğe ilişkin "bilme ve iktidar tertibatları" alanında öncü isimlerdir. Ardından Enoch Heinrich Kisch, William John Fielding, Theodoor Hendrik Van de Velde, Louis Bisch, Rudolf von Urban gibi psikolog ve jinekologlar cinsellik üzerine kitaplar yazarlar. Kraft-Ebbing'in ilk baskısı 1886 yılında yayımlanan Psychopatia Sexualis metni Türkçe’ye 1949 yılında, Tenasül Hayatımızda Bozukluklar ${ }^{15}$ adıyla çevrilir. Hem orijinal hem de çeviri metnin büyük bölümünü "fetişizm, sadizm, eksibisyonizm, mazoşizm, homoseksüellik, zoofili, pedofili” vakaları oluşturur. Kitap Foucault'nun ifade ettiği biçimde sapkınlığa ilişkin tıbbi söylemin adaletin de hizmetine koşulmasına bir örnektir. Mahkemelerde bilimsel inceleme gerektiren durumlarda yanlış hükümler verilmemesi amacıyla yazılmıştır ancak orijinal adında yer alan 
ve adli tıp alanına yönelik olduğunu belirten ifadeye çeviride yer verilmemiştir. Üremenin tesadüfe ya da insanın keyfine bırakılmadığı yolundaki argümanla açılan metne göre "tenasüli hayat, bazen kendi şahsını feda etmeye kadar varan yüksek faziletlerin memba1 olduğu gibi, manevi kudretin de en vahim hastalıklara sebep olmak ve en büyük ahlaksızlıkları husule getirmek gibi bir tehlike"16 barındırır. Öngörülemeyecek sonuçları yüzünden aşk da tehlikeli ${ }^{17}$ addedilir ve "zincirini koparmış bir hastalık"18 haline gelebileceği örneklerle aktarılır. Bu argüman, burada sözü edilen metinlerin hepsinde yer alan gizem, bilinmeyen ve tutumluluk olarak yorumlanan düşüncenin bir başka ifadesidir. Kraft- Ebbing'in kitabında sınıfsal farklılıklarla, "cemiyet ve kanun karşısında şehvet fazlalığı""19 gibi konular da örtüştürülür: "Tenasüli duyguları fazla olan kadınlar, mutat olarak, hali vakti iyi olanlar, (...) arasından çıkar. Hâlbuki erkeklerde Satyriasis, bazen içtimai tabakaların en alttakilerinde bulunur., 20

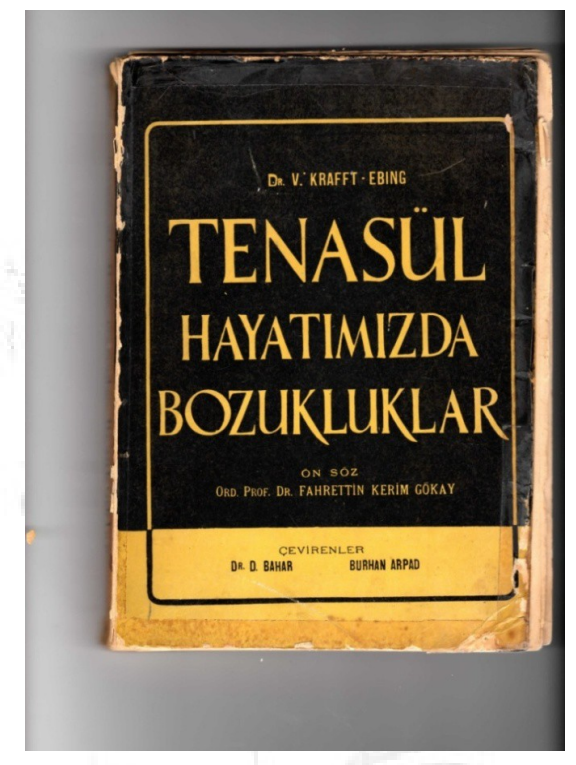

Seksoloji söylemi ahlak, din, görgü kuralları, cinsel sağlık ve fantezi gibi konuları ve dilleri birbirine eklemleyerek gündelik hayata sirayet eder. Çoğunda cinselliğe ilişkin örnek vakalar aktarılır, bu vakalar tarihten seçilmiş kimi olaylarla desteklenir, şair, yazar ve fillozoflardan alıntılara başvurulur, tıbbi görsel malzeme, grafik ve istatistiksel bulgular sunulur. Foucault, Hıristiyanlıktaki itiraf kurumunun dönüşerek cinsellik üzerine doğru söylem üretmedeki rolünü vurgular. Krafft-Ebbing'in metindeki örnek vakalara bakıldığında da anlatıların örnek vakalara nasıl dönüştürüldüğü görülecektir. Crozier ${ }^{21}$ de, Havelock Ellis'in metinlerinden yola çıkarak kişinin itiraflarının kullanılış biçimine ve anlatının, bir hastalığın inşasına nasıl dönüştürüldüğüne dikkat çeker. Tıbbi görseller, istatistikler ve grafikleştirilmiş bilgiler bu söylemde bilimselliğin kanıtı olurken, filozofların sözleri ve tarih de ahlakla ilgili derslerin çıkarıldığı uzama dönüşür. Bu dil Türkiye'de de benzer söylemi yürüten telif metinlerce benimsenir. $\mathrm{Bu}$ metinler arasında farklı bağlamlarda görünseler de evlilik tavsiyeleri ve kadınlara yönelik disiplin kitapları başı çekmiştir. Bu kitaplarda cinsellik tam da seksolojinin argümanları ile ele alınır. Çünkü seksoloji metinleri de kadının yaşamında olacakları, olay örgüsünü, aşamaları kurgular. Kadının yaşamı öğüt kitaplarında ahlak kuralları, dini inanç ve değerler ve birikmiş tecrübeler üzerinden kurgulanırken, tarafız olduğu addedilen bilim de kadın bedeninin kontrol altına alınması ve evliliğin düzenlenmesi bağlamında kullanılır. Sapkın duygular içinde histeri krizlerine yakalanan kadınlar, kocalarına ihanet edenler, evlilik öncesi cinsel ilişki yaşayan genç kızlar, çocuk doğurmayanlar, cinsellikte gerekenden fazla haz peşinde olan kadınlar hem ahlaken hem de bilimsel olarak kadın için belirlenmiş olan olay örgüsünü bozacaklardır. Öte yandan, Türkiye'de söz konusu tarihlerde cinselliğin bilimi adıyla yükselen bu alanda saha taramaları da yoktur. Bu nedenle örnek vakalar yerine yaz tatilinde bir başka şehre akrabalarının yanına ya da içkili bir toplantıya giden, dönemin tiyatro oyunlarını izleyen genç kızın başına gelmesi muhtemel olaylar, cinsellik ve ahlak alanında ders çıkarmaya yönelik kurgular ağırlık kazanır. Dönemin tıp kitaplarını dışarıda bıraktığımızda, hekim tanıklıkları ve örnek vakalar 1949 yılında aylık olarak yayımlanmaya başlanan Seksoloji: Cinsi Bilgiler Mecmuası'nda Türkiye'den tıp doktorlarının yazmış olduğu yazılarda ve derginin arkasındaki "Sual-Cevap" bölümünde daha 
çok yer alacaktır. 1943 yılında Cemal Zeki Önal'ın Evlilik ve Mahremiyetleri: Sevmek, Sevilmek ve Așkın Fizyolojisi $i^{22}$ adlı kitabı yayımlanır. Kitap yumurtalık anatomisinden İran Şahının aşklarına dek uzanan birbiri ile çelişebilen çok sayıda argüman ve bilgilerle doludur. Nietzsche ve Ovid'den birer epigrafla açılan metinde kadın ve erkek anatomisine ilişkin bilgiler ve seks deneyimleri, grafiklerle anlatılır; gebeliğe ilişkin tıbbi görseller kullanılır, şiir ve tablolarla süslü sayfalar arasında tanışma, ihanet gibi konular Joan Crawford'dan Napolyon'a uzanan isimlerden alınma sözlerle pekiştirilir. Türkler ve Hunlar hariç Araplardan Roma’ya, Germenlerden Hintlilere kadar tüm coğrafya ve kültürlerde aile ve kadın "tüyler ürperten bir fecaat sahnesi" 23 içinde anlatılır, "safahat" içinde eğlenenler, yakılan ve köle yapılan kadınlardan söz edilir. Metne göre "tarihteki bu perişan yuva" ${ }^{24}$ yı düzenlemeye kalkışan Hıristiyanlık olmuştur ancak İsa'nın evlenmemiş oluşu yaratarak Hıristiyanlığın da, kadının da kaderini kötü etkilemiştir.

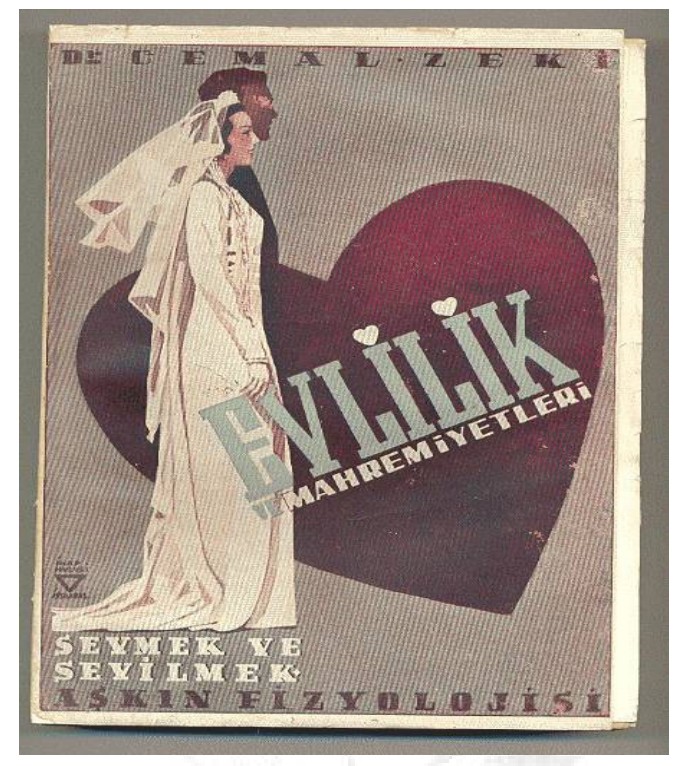

Benzer bir metin Hollandalı jinekolog Theodoor Hendrik Van de Velde'nin Mükemmel İzdivaç ${ }^{25}$ kitabıdır. Kitabın girişinde "Tercümeye İslamiyet ve Yüksek İzdivaç bahsi ilave edilmiş, Hıristiyanlığın dedikleri çıkarılmıştır” notu düşülmüştür. Yazarın yüksek izdivaçtan anladığı uygun eş seçimi, karşılıklı anlayış ve canlı bir seks hayatıdır. Kitabın sonunda eklenmiş olan “İslamiyet Yüksek İzdivaça Ne Diyor” başlığı altında Hıristiyanlığın tersine İslamiyet’te cinsel yaşamı düzenleyici kurallar olduğu anlatılır. Çeviriyi yaparak bu bölümü de ekleyen Ertuğrul Kayıhan'a göre İslamiyet, temizlik, yıkanma ve cinsel sağlık konularına çok önem vermektedir. Kayıhan burada cinsel ilişkiden önce ve sonra cinsel organın nasıl temizlenmesi gerektiği gibi konularda İslamiyet'in hükümlerini sıralar. Bunun dışında "inzal esnasında hayaline güzel bir yüz getirme" ve bereket getireceği düşüncesiyle evlendikten sonra kadının her iki ayağını yıkayıp bunun suyunu evin her tarafına saçması gibi öneri ve adetlerden söz eder ${ }^{26}$. Alıntıların Sufi Zade Seyyid Hulusi’ye ait bir görgü metni olan Mecmaüladab’tan yapıldığı söylenmiştir. Mükemmel İzdivaç, ağırlıklı olarak “cinsiyet fizyolojisi hakkında genel bilgiler, cinsi münasebetin fizyolojisi ve tekniği, beden sağlığı ve manevi sağlık” konularını ele alırken, açılışta yer alan ve Balzac'ı işaret eden epigrafı da seksoloji dilinin argümanlarına uyar biçimde "evlilik bir bilimdir" der. Bir diğer isim doğal ve şifalı sularla tedavi konusundaki uzmanlığı ile bilinen Enoch Heinrich Kisch'tir. Kisch'in, kadın fizyolojisini menopoz aşamasına kadar anlatan The Sexual Life of Woman in its Physiological, Pathological and Hygienic Aspects kitabı iklimler ve ülkelere göre istatistiksel bilgiler de verir. Bu kitapta yer alan bilgiler Türkçe'de yazarı belli olmayan, ya da Kisch'in de adının içinde geçtiği derleme metinlerde yer alır. Kisch, doğada yaşayan ve aşağı ırk hali olarak nitelediği "ilkel toplum”da kadının bir eşya olarak görüldügünü söyler. Bilim ahlak ve din dilinin bir arada kullanıldı̆̆ 1 metinlerden biri olan kitaba göre bekâret zaman içerisinde önemsenmeye başlanmış, bu sayede aile kurumu oluşmuş ve tüm güzellik ve iyiliklerin biçimlendiği bir ev kadını ortaya çıkmıştır. ${ }^{27}$ 
Bu metinlerin çoğunda kadın, sanat ve doğa arasında metonimik bağlantılara başvurulur. Krafft-Ebbing “Tenasüli mevzular olmasaydı, plastik sanatların ve şiirin hali ne olurdu?" diye sorar ve "büyük şair ve sanatçıların manevi bakımdan tabiate gayet yakın"28 olduklarını söyler. Böylece erotizm, cinsellik, sanat, kadın ve tehlikenin bir arada yer aldığı yeni bir uzam kurgulanmış olur. Şiir ve sanat da kadın ve cinsellik kadar öngörülemez ve tehlikeli alanlara dönüştürülür. Kisch'in metinlerinde de benzer dil oyunları vardır. Konu kadın cinselliği olduğu için tıp bilimi de sanat göndermesinden payını alır ve tarih boyunca "tıp sanatı"nın kadın cinselliğine olan ilgisinden söz edilir. Bu merakın nedeni elbette sadece jenital organ anatomisi değildir; üreme ile ilgili süreç ve hastalıklar, kadının cinselliği nasıl deneyimlediği de hekimleri ilgilendirmiş olmalıdır. Metin daha ilk sayfalarında, bilimsel dilin o ikna edici kanıtına başvurur ve kadının on yaşından altmış yaşına kadar cinsel yaşamındaki “yükseliş ve düşüş”ünü açıklayan grafiklere yer verir. Grafik, seksoloji ve erotik sanat arasındaki ayrımın semptomu olarak belirir. Dönemin dili ile Türkiye'deki karşılığı "münhani"dir ve seksoloji söyleminin sevilen araçlarındandır. Bu metinlerde milletler, iklimler, üremeye elverişli dönemler, fiziksel güzellik ve kalp atışları dâhil cinselliğe ilişkin her türlü bilgi, "münhani” halinde sunulur. Aşağıdaki grafik Van de Velde'nin Mükemmel İzdivaç kitabından alınmıştır ve kadının cinsel tecrübesine bağlı olarak farklı türevleri de $\operatorname{vard}^{29}{ }^{29}$. Grafikler bu metinlerde, konuşulması sıkıntılı addedilen ya da bilinmeyen bir alanda insanları eğitmeye yönelik olarak yer alırlar ancak ontolojik ve epistemolojik öncüllerini yansıtma biçimleriyle nesneleştirdikleri konuyu da olduğundan daha yabancı ve ciddi kılan şekillere dönüşürler. Kitapların bir kısmı erkeklere hitap eder biçimde yazılmıştır ancak çoğunda, kitap adı dâhil olmak üzere, seslenilen kişi kadındır ve bu kitaplarda da, yazar ister kadın isterse erkek olsun, kadından beklenen erkeğin taleplerini öğrenip içselleştirmesidir.

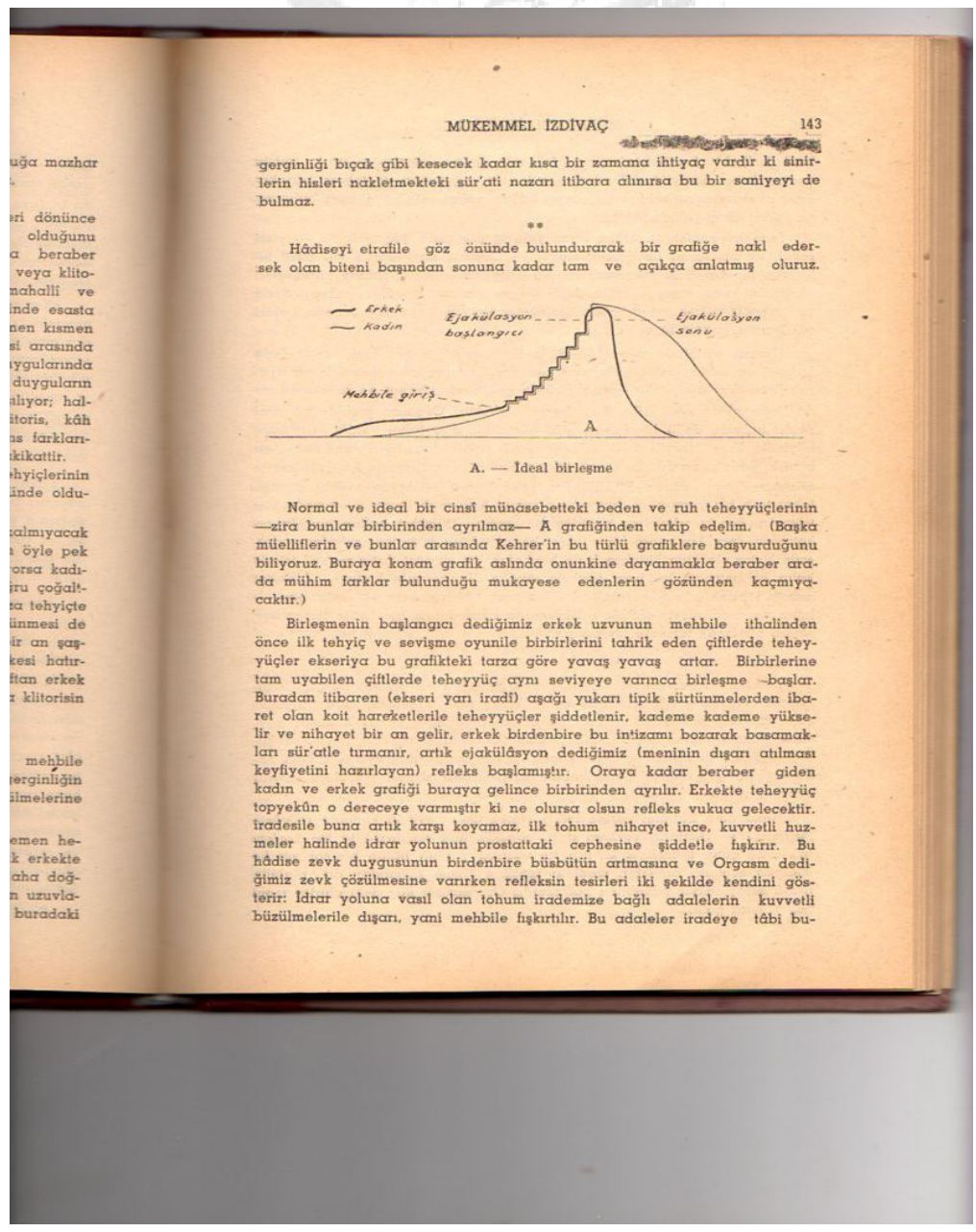


“Arzunun bilimi”"30 olma iddiasındaki bu dil 1947 yılında Amerika Birleşik Devletlerinde Alfred Kinsey ile birlikte kurumsallaşarak sosyolojik uzama çekilirken Türkiye'de de çok partili döneme geçilecek ve cinsellik ve ögüt kitaplarının sayısı artacaktır. Demokrat Parti'nin meclise girmesi ile basın ve yayın alanında da hareketlilikler başlamış, çok sesliliğe ve demokratik bir ortamda düşüncelerin ifade edilebileceğine inançla çok sayıda yeni gazete ve dergi çıkarılmış, yayınevi açılmıştır. Demokrat Parti, iktidara geldikten çok kısa süre sonra yeni bir basın kanunu ile gazete çıkarmak için bildirimde bulunulmasının yeterli olması, yayımlanan yazılardan gazete sahiplerinin değil, yazı işleri müdürleri ve yazarların sorumlu tutulması gibi yeni düzenlemelere gider. Bu arada ilk defa basın çalışanlarının özlük haklarına ilişkin düzenlemeler de yapılır. Ancak liberal ekonominin uygulanmaya çalışıldığı, özel girişimin özendirilmesinin hedeflendiği bu dönemde basın özgürlüğü vadeden Demokrat Parti ile basın arasındaki ilişkiler çok kısa zamanda gerilecek ve muhalif sesler yasak, sansür, tutuklama ve cezalandırmalarla karşılaşacaktır. Popüler romans kitapları ve burada sözü edilen türden metinler bir yandan bu dönemde yayımlanmasında en az sıkıntı olan yayınlar arasında yer alırlar, öte yandan yayın hakkı gibi anlaşmaları ve kuralları içeren piyasa ilişkilerinin, kapitalist iktisadın rasyonel dinamiklerinin ve kontrol sisteminin henüz içselleştirilmediği bu dönemde yayıncılığın birçok alanında özensiz çeviriler ortaya çıkar. Ağırlıklı olarak Hadise Yayınevi’nden basılan kitapların başlıkları ve kapak çizimleri de bu ortamda Kraft Ebbing'in "bilimsel ciddiyeti”ne artık ihtiyaç duymaz olurlar:
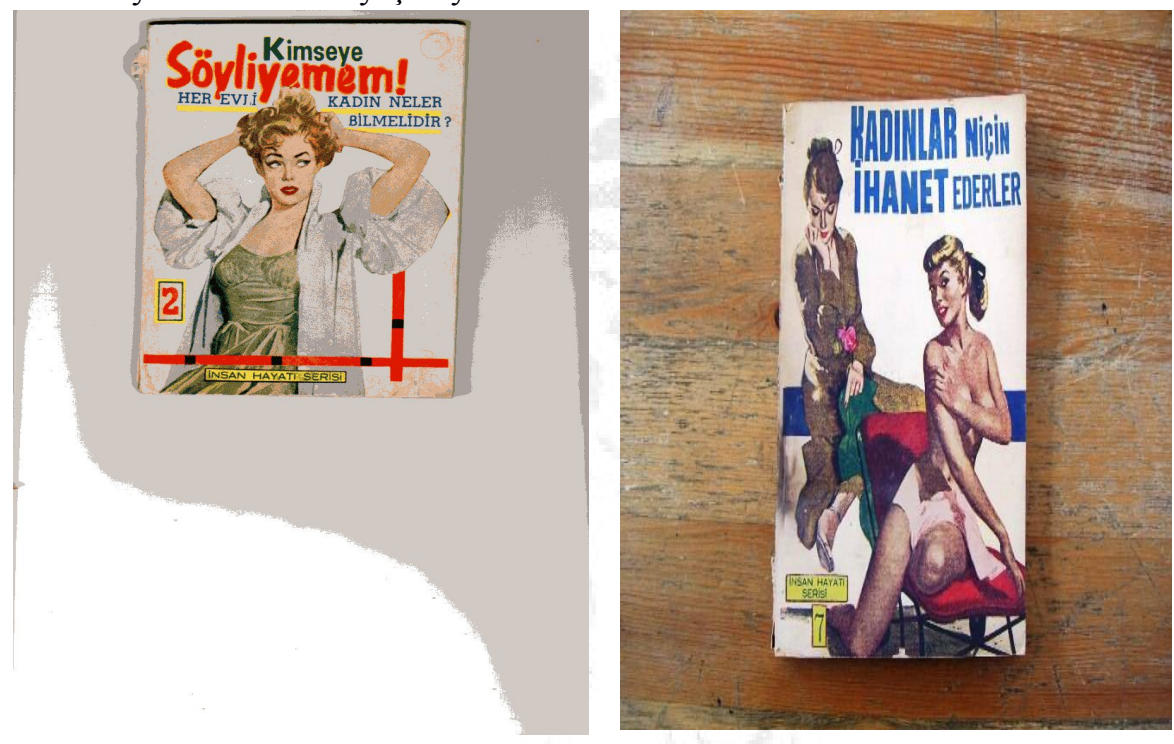

\section{Seksoloji Dergisi}

1949 yılına gelindiğinde Türkiye'deki telif ve çeviri seksoloji kitaplarına bir de dergi eklenir ve Amerika Birleşik Devletlerinde 1930 yılından itibaren yayımı süren Sexology: Modern Guide to Sex Knowledge dergisi, Seksoloji: Cinsi Bilgiler Mecmuası başlığı ile aylık olarak yayımlanmaya başlanır. Derginin yazı işleri sorumlusu Muzaffer Aşkın çevirileri arasında yer alan iki kitap dönemin ruhuna da uygundur. Bu kitaplardan biri William James'in 1948 yılında Milli Eğitim Bakanlığı yayınlarından basılan Pragmacılık ${ }^{31}$ adlı metnidir. Yararcılık ile eş anlamlı olarak da kullanılan pragmacılığın temelinde yer alan, deneye dayalı bilginin güvenilirliği, doğruluğun insanların deneyimleri ve içinde yaşadıkları toplumlara göre düşünülmesi gerektiği ve sağladığı yarara göre değişkenliği gibi, düşünceler rasyonalizm ile deneycilik arasında bir köprü inşa eder; çeviri de bu bağlamda Aydınlanma idealinden beslenerek modernleşmeye, kapitalist dünyaya eklemlenmeye çalışan dönemin Türkiye'si açısından oldukça faydalıdır. Aşkın'ın çevirdiği diğer metin Rudolph Von Urban'ın Aşk Sanat ${ }^{32}$ dır. Sevişmede "hazırlanış, müddet, dikkatin teksifi, gevşeme ve tekerrür"ün önemini anlatan ve cinsel hazzı elektrik akımı olarak açıklayan Von Urban, kurallara uyulduğu takdirde çiftlerin maksimum hazzı alabileceklerini yapmış olduğu tedaviler ve örnek vakalarla anlatır. Ancak kitaptaki öneriler antik dünyanın seks kılavuzlarında yer alanlarla aynıdır.

Seksoloji: Cinsi Bilgiler Mecmuası Türkiye'den tıp hekimleri, psikiyatr, sanat tarihçisi, gazeteci-yazar ve hukukçuların yazıları ile yabanıı tıp hekimlerinin ve seksologların çeviri makalelerini içermektedir. Burhan 
Öncel, Kazım Arısan, Samih Nafiz Tansu, Peyami Safa, Kemal Çağlar, Bülent Davran, Rasim Adasal, Turgut Uran, Nuri Kodamanoğlu, Kayıhan Uraz, Türkiye'den yazan isimler arasındadır. Dönemin seksoloji kitaplarında yapılan burada da tekrarlanmış ve yazıların arasına yazar ve şairlerden seçme sözler serpiştirilmiştir. Okur bu sayede, bir sayıda Turgenyev'in "Bütün eserlerimi, akşam yemeğine geç veya erken gelmemle ilgilenen bir kadın uğruna feda etmeye razıyım"33 itirafını, bir başka sayıda Michelet'nin "Kadın kocasının zulmünden değil, aldırışsızlığından üzüntü çeker" ${ }^{4}$ dediğini öğrenir. Hemen her sayıda izlenebilen bölümler arasında "Dünyadan Cinsiyet Haberleri” ve "Ünlülerin Aşk Mektupları", gibi başlıklar yer alır. Bu bölümler ötekinin ya da tarihsel ve uzamsal olarak uzaktakinin cinsel yaşamına ilişkin fantezilere zemin hazırlarken, fantezinin sınırlarını açar, koordinatlarına işaret eder. Ancak başkalarının cinsel yaşamı ve "Cinsel garabetler” yalnızca Türkiye'deki dergiye özgü değildir, örnek alınan dergide de benzer bölümler vardır ve "sapkınlık" ve ötekinden söz etme üzerinden gelişen seksoloji söyleminin bir diğer semptomudur. Dünyadan cinsiyet haberleri arasında Yeni Gine yerlilerinin evlenme ve cinsellik pratikleri ${ }^{35}$ gibi antropolojik başlıkların yanı sıra seksoloji söyleminin fantezi merakına uygun biçimde "Niğde'de tavşan doğuran kadın" ${ }^{36}$ haberlerine rastlanır. Kimi zaman da savaş nedeniyle Kore ve Japonya'da bulunmuş bir askeri hekim Japonya'da gezdiği ve "Genç Kızlar Barı, Dullar Barı, Apaş Kahveleri, Geyşa Evleri” ve Japon Hamamları” olarak adlandırdığı eğlence mekânlarını neşe içinde ve övgü ile anlatır ${ }^{37}$. Seksolojinin birincil fantezi alanı kadının cinselliği ise hemen ardından gelen de uzaklarda olanların ya da benzer olmadığı düşünülenlerin fantastik bir kurgu içine yerleştirilmesidir. Derginin kimi sayılarında yer alan "Cinsi Garabetler" ve "Garip Cinsi Hadiseler” gibi kısa bölümlerinde ise bir kadının kalın bağırsağına açılan rahim ağzı, çocuk doğuramadığı için ölen kadın, altı göğüslü kadın gibi örneklerden söz edilir. Ancak Amerika Birleşik Devletlerinde yayınlanan dergide de benzer biçimde "Curiosities" bölümü vardır. Bu bağlamda insan anatomisindeki sıra dışılıklara, farklılıklara, ortalamanın dışında kalana, hastalıklara olan bu ilginin arka planında mitolojiler ve masallardan beslenerek gelen ve fantastik olana duyulan merakın da yattığını düşünmek mümkündür. Derginin konularını kadın ve erkek cinsel sağlı̆̆ı ile evlilikle ilgili sorunlar oluşturmaktadır. Kadın ve erkek cinsel organları çizimlerle, fotoğraflarla detaylı biçimde tarif edilir, fiziksel güç ve cinsel iktidar arasında bağlantı olup olmadığı sorgulanır, cinsel eğitimin nasıl ve kimler tarafından verilmesi gerektiğine ilişkin, nerede nasıl yapıldığı çok da açık olmayan, anket sonuçları verilir.

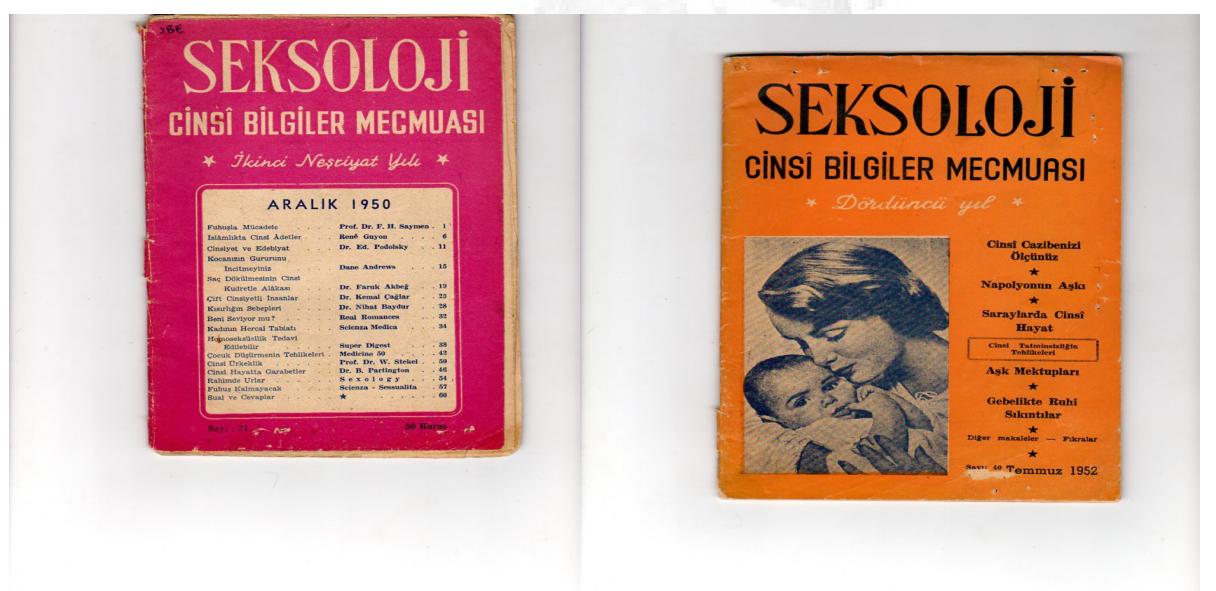

"Sual ve Cevaplar” bölümünde okurlardan gelen sorulara kimi zaman çizim ve grafiklerle yanıt verilir. "Alkol ve İrsiyet"38 başlığında bir okurun sorusu şöyledir: "Sarhoşluk esnaşında cinsi münasebette bulunan kimselerden hâsıl olacak çocukların muhakkak ahmak ve dejenere oldukları ve ana-babalarının bu alkol iptilaları veya uyuşturucu madde kullanma itiyatlarının çocuklarına da intikal edeceği kesin olarak söylenebilir mi?" Aşağıdaki çizimle desteklenen yanıt ise kendi içinde oldukça çelişkilidir. Alkolizm ve uyuşturucu kullanımının iktidarsızlık yarattığı, bedeni zehirlediği, topluma zarar verdiği anlatıldıktan sonra bu tür "iptila ve itiyatlar irsi olmayıp sonradan kazanılan alışkanlıklardır" denir. Ancak çizim, yanıtın tam tersi biçimde akıl sağlığı, ve alkolizmin spermlerde saklı olduğu yolundadır: 
Dergide hangi kadınların kolay koca bulamayacakları sınıflamalar üzerinden anlatılırken kadınlara doğru davranışı öğretme yollarından biri de ünlülerle yapıldığı iddia edilen konuşmalardan geçer. Bob Hope, Fred Astaire, Tyrone Power, Gary Cooper, Robert Taylor, Victor Mature ve James Stewart gibi ünlüler evli oldukları kadınları sevme nedenlerini sıralarlar. Bu isimlere göre bir kadın, kıskanç olmadığı, bir başka erkeği methetmeye kalkışmadığı, kocasının ceplerini ve cüzdanını karıştırmadığı, ağlamadığı, kocasının gece yemekten sonra uzanarak gazete okumasına karışmadığ münakaşa etmediği, başkalarının yanında iltifat beklemediği için sevilmektedir. ${ }^{39}$ Sayılan gerekçeler burada sözü edilen metinlerin hepsinde kadına yapılan uyarılar arasında zaten yer almaktadır. Öte yandan sinema ve roman tüm metinlere göre tehlikelidir. "Sinema Şehveti Gıcıklar mı?" 40 başlıklı yazıya göre sinema perdesi ve afişlerdeki aşk sahneleri gençler üzerinde olumsuz etkiler bırakmaktadır ve ahlak kurumları da bu duruma karşı çıkmakta haklıdır. Benzer argüman Seksoloji ve Gençlik Hayatı adlı haftalık serinin ilk sayısında da yer alır. "Dış Tesirler Altında Duygulanan Bakireler" başlığında "Maurice Hewletts'in Âşıklar adlı kitabını okuyunca herhangi bir gençle tatmin edecek hale gelen genç kız" ve "Emile Zola'nın Nana'sını okuyunca nefsine hâkim olamayacak kadar huylandığını belirten bakire" ${ }^{41}$ gibi örnekler verilir. Kisch de, kadınların sadakatsizliği konusunda "aşikane romanlar okumak, açık saçık revülere gitmek, teşhir edilen çıplak sanat eserlerini görmek, tiyatrolarda evlilik sadakatine aykırı piyeslerin temsillerinde bulunmak" ${ }^{42}$ gibi bir dizi neden siralar.

\section{Mükemmel Eş}

Sözü edilen metinlerin hepsi kadın ve mükemmellik tanımları geliştirmeye çalışırken kadının önce anne olduğunu söylerler. Bir metin "Yaşlı Bakirelerin Çektikleri Izdıraplar” başlığında "rahim tümörü” ve “ "vulva takallüsü”nden söz ederken, evlilik öncesindeki seks hayatının nelere yol açabileceğini de "parçalanmış zar", "flört sırasında iğfal edildiği için cinsi arzulara hâkim olamamak", ve "anormal münasebette bulunmaya alışmak" 43 gibi ifadelerle betimler. Cinsi duygularını sınırlandıramayanlar dejenere olarak nitelenir ve fiziksel görünümden de anlaşılacağı söylenen bu hal Kisch' göre "irsi"dir. Kisch, "Fenalık ecdat kanında bulunur" ${ }^{44}$ derken, anne kadar, babadan da bir aktarım olabileceğini belirtir ama betimlediği de bir kadındır: "Deforme kulaklar, alt ve üst çenede suiteşekkül, haddinden fazla küçük veyahut ileriye çıkıntılı dişler, burun kanallarında gayritabiîlik, tiroit guddesinin büyümesi veya pek çok küçülmesi, yüzde sakal ve bıyık yerlerinde kuvvetli kıl gelişimi"45 dejenere olmanın önemli ipuçları sayılır. Ayrıca "sara nöbetlerini andıran histeri hamleleri” içinde yaşayan ve bekârlık dönemi uzadığında, "sarı benizli, gözlerinin çevresi siyahlaşmış, çarpıntılı, iştahsız, hazımsız"46 bir hal alanlar da vardır ve "cismen bir bakire ama ahlaken tamamile bozulmuş... muhayyilesi erotik sahnelerle dolu", "ahlaki şuurdan, hakiki edep ve terbiye mefhumundan ve kadınlık faziletinden nasibini" ${ }^{47}$ almamış bu kızlar bekaretlerini korumalarına rağmen evlendiklerinde sağlıklı çocuklar yetiştiremeyeceklerdir:

“... böyle mütereddi bir kadın annelik hakkında, onun zevkine ve vazifelerine dair hiçbir şey öğrenmek bilmek istemez. Esasen bu vazifeleri yerine getirmek için fiziki kabiliyeti de azdır; ya zayıf gelişmiş veyahut da süt guddelerinden ziyade yağ nesci ile dolu olduğundan memeleri çocuğu beslemeye yetecek kadar süt vermez." 48

Bunun dışında bütün kitaplarda evlenmemiş kadınlar "aile terbiyesinden uzak, cahil ve basit" 49 olarak nitelenir. Anlatıcının anne olarak kurgulandığı bir metin ${ }^{50}$ kadınlara "bedenlerini "mukaddes bir şey" olarak görmelerini öğütlerken bu alanda yazdığı iki kitabında seksolojinin argümanları ile konuşan Kemalettin Tuğcu da erkeğin "kuru toprağı" değil, "en büyük şeref ve namus addedilen” kadınları korumak için sınıra koştuğunu yazar" $^{51}$. Yazara göre kadın "milli namustur...ortaya kendi cinsinden, milli bir varlık, babası belli bir insan getirecektir" 52 Metinlerin bazılarında yazarın ya da çevirmenin önsözü, kitabın nesli, ulusu ve kadını korumak ve yüceltmeyi hedeflediğini belirtir. Çeviri metinlerde buna bir de Türk ve Müslüman kadını içten ve dıştan gelecek olan tehlikelere karşı korumak, Türk kadınlarının yüksek karakteri ve ahlaklı oluşu, Türklük, Müslümanlık ve geleneklere yönelik övgüler eklenmiştir. Burada kadın bedeninin milli namus ile özdeşleştirilmesi çok da sıra dışı bir durum değildir. Najmabadii ${ }^{53}$ de vatanın sevilen kadın bedenine dönüştürülmesi ve kadın bedeninden vataniyat yayıldığı gibi tahayyüllerden söz eder. Ancak kadını, sınırı, milli namus ve bekâreti korumak üzerinden geliştirilen bu dil vereceği güvenlik hizmetinin karşılığını isteyecek ve erkeklerle geçinmeyi bilmek gerektiğini söyleyecektir. Bu bağlamda kadının başarısı da uyumlu olmaktan geçer, aile kavgalarını büyütmek gereksizdir ve insanın en önemli özelliği "hayata uyuş" 54 tur. Kadınlara "ana" diye hitap eden ses sözü edilen tüm metinlerde geçen metaforlara başvurur: "Aileyi bir saate benzetirsek kadın onun zembereğidir. Aile bir fabrika ise kadın da 
bir motördür. Aile bir sürü ise kadın onun çobanıdır." ${ }^{55}$ Uyumla ilgili bir diğer metafor da Önal'dan gelir, Önal mutlu yuvanın koşullarını sıralarken kadının uysallığı üzerinde durur ve "Kadın bir su gibi olmalı kocasının hayat kabına döküldüğü zaman bu su, kabın şeklini tamamile almalıdır." ${ }^{56}$ der. Tuğcu ise, evlilik kurumu dişında düşünemediği kadına boşanma konusunda çıkışır:

"Bazen bir bazen iki bazen beş sene içersinde ayrılmaya kalkıyorsunuz. Bu beş senelik zaman daima onun fenalıklarile mi geçti? Beş sene tahammül etmeniz sizi mazur gösterebilir mi? Beş sene içinde ıslah için uğraştınız mı? Bütün çarelere başvurdunuz mu? Hayır, bir hianet, bir mahrumiyet, bazen bir giyim eşyası, bir geçim meselesi yüzünden hemen dirsek çevirdiniz." 57

Tuğcu bir diğer kitabında boşanmanın kötülüğü ve kadının hassasiyeti arasındaki bağlantıyı vurgulamak için ikinci evliliğinden doğurduğu çocuğun ilk kocasına benzediğini görerek şaşıran ve acı çeken kadın örneğini verecektir. Bu durumun tıbbi ve manevi açıklaması "ilk erkeğin kadının maddesine ...dimağına... hatırasına" 58 işlemesidir. Örnek, başka metinlerde de yer alır. Burada söz konusu olan, cinsellik alanını bilimsel bilgi ile açıklamaktan vazgeçmek değildir; yapılan bu alanın bilimsel bilgisine erişimi olmayan okurda korku yaratmaktan ibarettir. Bu bağlamda burada ele alınan metinler modernleşme ile birlikte kadın erkek ilişkilerindeki olası dönüşümlerinden duyulan tedirginliğin semptomları ve birer gözdağı verme aracına dönüşürler.

Metinlere göre erkeklerle geçinmenin yolu ev hayatı ile erkeğin dışarıda geçen zamanını uyumlu kılmaktır ve erkek, "Evine yarı geceden sonra gelse bile, yuvasında kendini bekleyen bir insanın, sözlerini dikkatle dinlemeye hazır bir çift kulağın mevcudiyetinden emin olmalıdır." ${ }^{59}$ Arsan, bu konuda bir adım daha ileri giderek "Bütün hareketlerinizi kocanızın tip ve karakterine göre ayarlayacaksınız. Kocanızın zevk aldığı ve meşgul olduğu şeyler sizi ikinci derecede alakadar eden mevzular da olsa sanki siz de onun kadar heyecan duyuyor ve zevk alıyormuşçasına o mesele ile meşgul olacaksınız." ${ }^{\prime 0}$ öğüdünü verir. Burada söz konusu olan erkeğin stratejisine karşı kadın olmayı kullanarak taktikler geliştirmeye ve durumu idare etmeye işaret eden gündelik yaşamın dilidir. Sıklıkla vurgulanan bir diğer konu erkeklerin "ham" ${ }^{61}$ ve "yetişkin bir çocuk" ${ }^{62}$ gibi oldukları ve kadınların da hormon ve duygusallık arasında yaşadıklarıdır.

Erkeğin beslenmesi, erkek, hem erkek hem de çocuk olduğu için o kadar kritik bir mevzudur ki, Arsan "Yorgun ve aç kocanızın önüne bir iki tabak temiz yemek çıkaramayacak kadar aciz içinde iseniz esasen böyle bir birliği de kurmaya hakkınız yoktur." ${ }^{63}$ diyecektir. Dahası, kocayı "temiz ve tertipli gezdirmek", yemek sırasında "en mutena parçaları ona ikram etmek" ve "çabuk hazmedebileceği yemekleri pişirmek" ${ }^{64}$ gerekir. Mükemmel kadın da erkeğin çocuk, kadının anne oluşu üzerinden tanımlanır:

"İyi bir ev kadını sabah erken kalkar. Kocasının ihtiyaçlarını yakinen bilir ve onu

o şekilde hazırlar ki, kendi temizliği kocasının her yerinden belli olsun.

Bekârken annesi ona iyi bakıyordu, karısı neden daha iyi bakmasın? Şimdi onun

o kadar genç ve o kadar enerji dolu karısı var ki!"65

Tüm bu öğ̈̈tler kadına erkekle başa çıkmak için taktikler verirler. Bu Certeau'nün ${ }^{66}$ egemen olanın siyasal ve iktisadi bağlamda inceden inceye işlediği ve kurumlarıyla da yerini sağlamlaştırdığı stratejisi karşısında, o andaki gereksinimleri doğrultusunda çareler, kurnazlıklar ve gizli yollar arayan, üreten zayıfın taktikleri ayrımını da hatırlatır. Ancak taktikler sadece durumu kabullenmeye ve anı kurtarmaya yararlar.

\section{Gizem, Gizlilik}

Evlilik üzerinden kadın ve erkeklere verilen öğütler metaforlarla süslenirken esas konu bilinmezlik, gizlilik ve gizem arasındaki geçittir. Bu bağlamda seksoloji söylemi sadece seks teknikleri ve cinsel sağlı̆̆ değil aynı zamanda kadının yaşamını da kurguladığından Foucault'nun iddia ettiği gibi cinselliği değil, kadını gizlemeye hizmet eder. Gizlilik kimi zaman kadının ortalarda görünmemesi ve kocanın "müsaadesi olmayan" yerlere gitmemektir $^{67}$. Öte yandan erkek, kadının sınırlı derecede anlamasının kâfi bulunduğu işlerini, sahip olduğu deneyim ve bilgi birikimini kadınla paylaşmaması üzerinden gizemli kılınır. Gizlilik erkeğe ve kadına farklı biçimlerde sirayet ederken keskin karşıtlıklarla tanımlanan kadının bilinmezliği vurgulanır:

"Dünyanın en çetin muamması olan kadın işte böylece hayatın mihrak noktasında ya etrafına iyilik, rahmet ve nur saçan melek simasile veyahut zehir kusan bir engerek yılanı kafasile dikilerek ya mukaddes aile ocağının bir tacı ve yahut da öldürücü mikroplarını ta gelecek nesillere aşılayan bir 
fenalık kaynağı, ya annelik kalesini fethetmiş bir kahraman veya şehvetin mağlubu sefil bir köle olarak görünür." 68

Kurumun ve dolayısıyla iktidarın da özünde bulunan gizlilik ya sahip olduğu gizleri birbirini korumaları için organize edecektir ${ }^{69}$ ya da ortada bir giz varmış gibi yapacaktır. Metinlerde evlilik kurumu da metaforlarla gizemli kılınır. Theodor Van de Velde'nin kitabı İngilizce çevirisinde "Araf" metaforu üzerinden açılır ve bu gizem Türkiye'de yayımlanan kitaplarda da farklı versiyonlarla yürütülür. 1930ların ikinci yarısında Daniş Remzi Korok'un yazdığı bir dizi “risale”den Genç Kızlara Göre İzdivaç ve Zifaf adlı metin, literatüre, Ricoeur'ü izlersek tüm metaforlar gibi bir "semantik yenilik", bir "muamma" ve "gerçeklik hakkında yeni bir şey" olan, "izdivaç kutusu” metaforunu ekler:

"İzdivaç kutusu derhal açılmaz. Onun her ait olduğu genç kız kalbinin mukadder ömrüne göre bir açılış zamanı vardır. İşte o zaman gelince kutu kendi kendine açılır ve kapağı kendi kendine kalkarak içindeki cevheri veya cevher çıkacak derken içinin tamamile boş olduğunu gösterir....

Demek oluyor ki izdivaç bir muammadır. Bir sırdır. Bir piyangodur."70

Kadına ilişkin gizem ve gizlilik birden fazla biçimde işletilir. Kadından öncelikle, kendini ve dünyayı tanımadığı varsayılarak dikkat çekecek davranışlardan uzak durması ve ağırbaşlılık, kendine inanmak ve bir amaca sahip olmak üzerine kurgulanan "kadınlık sanatı"nı öğrenmesi istenir. Bunun için de günde yüzer defadan beş günde beş yüz defa "Başka insanlar ve şeylerle ilgileniyorum" ifadesini yazması, oda kapılarında bir saniye durma egzersizi yapması, "günaydın, ne enteresan, yine buyurun” demeyi öğrenmesi, konuşmalarda kullanabilmek için bebeklerden operalara kadar yirmi dört kısa konu yazarak aklında tutması, konuşmalarda konuyu farklı yerlere çekebilmek için "müzik, ampul ve ilim” kelimelerini seçerek bunlardan çıkarılabilecek tartışma konularının bir listesini yapması, hiçbir konuda fikrinin olmadığının düşünülmemesi, ama her konuda bilgili olduğunun da zannedilmemesi için bir toplantıda ikiden fazla kanaat açıklamamaya özen göstermesi, isimiyle aidiyet kurabilmek için her gün aynı saatte bir yere giderek ismini yüksek sesle söylemesi öğ̈̈tlenir. ${ }^{71}$

İkinci olarak "herkesin meçhulü olmak"72 kadının başarısını gösterdiğinden, kadın gizemli kalmayı öğrenecektir, ancak bu da erkeğin, bilimsel olarak da desteklenmiş biçimde çabuk bıkan bir varlık olduğu düşüncesi üzerine kuruludur. Bu nedenle de kadına "kendinizi ilk günlerden beri tam bir cömertlikle kocanızın önüne sermeyiniz(...)kendinize mahsus ileride kullanabileceğiniz ufak tefek sırlarınız bulunmalıdır" ${ }^{\text {"3 }}$ öğütleri verilir. Korok'un evlilik kurumu üzerinden geliştirmiş olduğu kutu metaforu, Arsan'ın metninde de yer alır: "Kadınlığın hususiyetlerini teşkil eden bu sırlar koca tarafından birer birer çözüldükçe daha fazla heyecan ve helecan doğuracaktır. İçinden ne çıkacağını bildiğimiz bir kutu bizi heyecanlandırmaz ama bilmediğimiz bir paketi açarken başlayan sabırsızlık, içine ulaşıncaya kadar gayrı ihtiyari artar." 74 Benzer biçimde Tuğcu da kadının kocasına "açılıp saçılmama"sını, "ruhunu ve vücudunu büsbütün teslim etmemesini” ve biraz naz, biraz çekingenlik" yapmasını ve "küçük bir mukavemet"i öğütler. ${ }^{75}$ Bu bağlamda seksoloji dili kendi içinde iki farklı anlamda tutumlu olmaya işaret eder. Bir yandan normal ve patolojik çizgisi üzerinde aşırılıkları sınıflandırarak haz ve davranışlarında kadını ölçülü olmaya çağırır, öte yandan erkeğin çokeşli olduğu gerekçesiyle kadın "kendini damla damla vermelidir"76 der. Tuğcu, erkeğin bıkkınlığının üstesinden gelmek için kadına pratik yollar da önerecektir. Gecelikleri farklı renk ve biçimlerde yapmak çözümlerden birisidir ancak bütçe elvermiyorsa bunun da çaresi vardır: “(....)Kadın kendini değiştirebilir. Saç tanziminde başkalık, bir kurdela ilavesi, nihayet bir soyunma tarzı, hulasa bir akşam evvelki kadında olmayan bir eşya veya hareket lazımdır. (...)Bunları da yapamazsanız karanlıkta soyununuz ve karanlıkta yatınız. Hulasa her gecenizde bir başkalık bulunsun." 77 KrafftEbing de kadının "mevcudiyeti" için bir savaş vermesini söyler ve "ara sıra ufak müsaadekarlıklarda, lütuflarda bulunması, sonra tekrar çekingen bir hal alması" ${ }^{78}$ önerisini yapar. Değişkenlik, Krafft-Ebbing’e göre kadının yaradılışında vardır. Bu bağlamda mükemmel eşin bir diğer özelliği yeknesak olmamasıdır. Sıklıkla tekrarlanan bu tema aslında dizi filmlerden oyuncaklara dek popüler kültürde yaygın yer kaplar.

"Zaman zaman benliğinizi başka insan kalıplarına dökmesini bilmelisiniz. Bugün çok şen, yarın ufacık bir şeyden hırslanan, bugün nazik, yarın hoyrat, birkaç gün intizamsız, sonra derli toplu oluverin. Bunu yalnız kendinizde değil, evinizde ve odanızda da yapacaksınız. Kocanız senelerce aynı koltuğun aynı köşede tozlanmasından içinde garip bir miskinlik duyacaktır.,"79 
Uyarıların gerekçesi bellidir ama erkeğin “gözünün dışarıda olması"nın nedeni de yine "dişiliğin icap ettirdiği tahrik edici hareketlerde bulunmayan, balık yemeğe meraklı samimi dostlarının eve gelmesinden hoşlanmayan", erkeğin "arada sırada psikolojik bir zaruret olduğu için banyoda kendi başına kalmasına başına izin vermeyen" 80 kadındır. Bu durumda kadını bekleyen "metres faciası”dır. Çünkü metresler, "erkeklerin ruh hallerini, isteklerini, neden haz duyduklarını kolayca keşfetmek maharetine sahip olan" ${ }^{81}$ dolayısıyla da gizemin "gayri tabilik"le ilgili bir durum olduğunu kavramış kadınlar olarak tanımlanırlar. Aynı konu Tuğcu’nun da dikkatinden kaçmamıştır:

"Kocanızı kadın ihtiyacı içinde bırakmayınız. Bazen herhangi bir sebepten darılır, kocanızın yanında yatmazsınız. Onu kendinizden mahrum etmenin bir ceza olduğuna ve gelip size yalvaracağına inanırsınız. Bunu çok defa yaparsınız. Fakat bu nadiren kullanılması lazım gelen bir harekettir. Eğer kocanız sizi her zamanki yerinize davet etti de gelmediniz mi, ertesi sabah onu başka kararlar vermiş bir adam olarak görmeniz mümkündür. Sihhatli bir erkeğin her hareketi muntazam ve muayyendir. Siz bunu bilirsiniz. Siz bu itiyadlara mukabele etmelisiniz. Siz onun karnının doyurmalısınız ki başka yerde yemek yemeğe kalkmasın." 82

Gizlenmenin üçüncü nedeni ise kadın bedeninde erkeğin hoşuna gitmeyen ve tiksinti uyandıran özellikler bulunduğu fikridir. Bu bağlamda gizlenmesi gerekenlerin başında "her ay tekerrür eden malum rahatsılzlklar" ve hamilelik döneminde değişen beden gelir. Kadının kocasına her zaman tüllerle örtülü biçimde görünmesi, hastayken ayrı yatağa geçmesi ve hamile karısı ile dolaşmak istemeyen erkeği "hürmetle" karşılaması önerilir. Tuğcu erkeklerden saklanması gerekenlere kadınların ayaklarını da ekler ve "Kocanıza çıplak ayağınızı göstermeyiniz" diyerek ayakkabılı ve çıplak ayak arasındaki farkları anlatır ve "Ayağın bütün bacakla birlikte, güzel bir çorap ve ökçeli iskarpin veya terlikle arz etiği güzel manzarayı ve kazandığı sevgiyi, onun bütün çıplaklığı ve kusurlarıyla birlikte erkeğe göstererek kaybettirmemek lazımdır." 84 öğüdünü verir.

\section{Fazilet ya da Sapkınlık}

Kadın, vatan, ev, mutfak ve rahimle temsil edilen görevlerini tamamlarken cinsellikten alınacak "hazzın ahlaksal olarak sorunsallaştırılması" 85 üzerinden yeni bir uyarı ile daha karşılaşır. Evliliğin kadınları hastalık ve ahlaksızlıklardan koruyan bir kalkan olarak kurgulandığı bu metinlerde evlendikten sonra da uyulması gereken kurallar vardır: "Münasebetten sonra yorgun hissetmemelidirler. Ertesi gün kendilerini bir gün önceki kadar zinde ve kuvvetli hissetmelidirler. Ĕger, kendinizi isteksiz hissediyorsanız, eskisi gibi içinizde kendiliğinden bir arzu doğmuyorsa, itidal hudutlarını aşmıș, ifrata girmișsiniz demektir." "86

Kimi metinlere göre kadın, evliliğin ilk gecesini "uykusuz geceler" geçirerek ve bir erkeğe "siz" yerine "sen" diye hitab edebilmek için beklemektedir ${ }^{87}$ ve erkek de "yaradılışı icabı pasif" olan kadını "tedavi edecek" 88 kişidir. "Mukavemet" konusu bir başka bağlamda daha gündeme gelir. Konu bu defa gizemi sürdürmek değil, cinsellikten alınacak hazzı kontrol etmektir. Kadından beklenen kontrollü davranış, "bir fahişede bile rastlanabilen kadınlık ar ve hicabı (...)yırtılmamış kadın sıkılganlığı"89 olarak betimlenir. Kisch'e göre kadın, "içten gelen imanın tevlit ettiği ahlak ve şuur(...) yaradılışında olan analık aşkı(...) din, kanun ve ahlakın çizdiği hudutlar" gibi gerekçelerle "mukadderatına boyun eğmek" durumundadır: "Onun seksüel temayülleri dinin, kanunların ve ahlakın çizdiği hudutlara inhisar eder. Fakat bu hudutlar içinde dahi kadına seksüel zevkini tatmine yetecek kadar bir hareket sahası kalır." ${ }^{90}$ Erdem ve sapkınlık arasındaki sınırı belirleyen sadece gelenek ve inanç değildir, aynı zamanda namus kurallarına uymak, haram olandan çekinmek, dürüstlük kadının yaradılışında da vardır ve bu peygamberlere atfedilen ve tanrı tarafından korunmuşluğu, masum olmayı anlatan "ismet" sıfatı ile de vurgulanır:

"Kocasile cinsi münasebetten edep ve iffet dairesinde ve sakin bir halde zevk ve huzur duyar, itidal derecesinde zevkle iktifa eder ve zaten inhimaki olmayan zevk ve sefa sarhoşluğuna hiçbir zaman kendini kaptırmaz. Bu tip kadının fazileti kendi tabii desteğini iman ve itikatta, ananeye derin bir bağlılık duygusunda ve yaradılışındaki iffet ve ismetinde bulur. Bunlar kendisine koca sevgisini ve evliliğe sadakati Allah'ın emri olarak tanıtır ve hilafina hareketin günah ve cezayı müstelzim olduğu korkusunu telkin ederler." "91

Öte yandan "yaradılıştan masum” olduğu söylenen kadının "dışarıdan” gelebilecek tehlikelere açık oluşu iki biçimde temellendirilir. Öncelikle kadın, "ruhunda aynı zamanda hem iffet hem de fuhuş isteğgi" 92 taşır 
ve kocasına ihanet edebilir. Fuhuş isteği olan kadınlar evlendikten sonra "şehvet duygularını gıcıklayacak en kötü romanları okuyabilecek(...)seksüel damarlarını kabartacak temsilleri hiç sıkılmadan rahat rahat seyredebilecek" ${ }^{93}$ yaradılıştadırlar. Aynı metin hayvanat bahçesinde yapılan bilimsel gözlemlerden hareketle hangi tür kadın ve erkeklerin birbirlerine ilgi duyduğu yolunda da açıklamalar yapar:

"Herkül gibi bir erkek vücudu ve demir gibi kuvvetli bir bilek narin yapılı kadınlık için cinsiyet temayülleri sahasında bir idealdir. Kuvvetli bir hükümdar, zalim bir serdar, boyun eğmez bir kahraman tesiri yapan erkek zayıf ve iradesiz olan kadının aşıkane meyil ve sevgisini çok kolay elde eder. Kocalık haklarının verdiği gururla böbürlenen atılgan, mütecasir bir erkek, ürkek, uysal ve teslimiyetkar olan kadın üzerinde son derece cazip bir tesir yaratır." 94

Yazar "zayıf kadının kuvvetli adamdan, kuvvetli kadının kendisine muti bir bende gibi muamele edecek" erkekten hoşlanabileceğini, "aristokrat bir kadının kaba bir köylü tipi" 95 ni seçeceğini söylerken kendi tanıklıklarını da devreye sokar ve "aralarında iğrenç suratlı tek göz bir adam ile cüce bir kanbur bulunan bir takım çirkin ve tam manası ile malul erkeklerin, acınacak birer sefalet manzarası arz etmelerine rağmen, en güzel kadınlar tarafından apaçık tercih olundukları..kocalarının üstüne bunlarla günah işledikleri" ${ }^{96}$ nden söz ederek cinselliğin yol açabileceği sapkınlıklara örnek vermeye çalışır. Tüm bu betimlemeler elbette cinselliğin varsayılan sınırları aşıldığında olabileceklere yönelik uyarılardır. Çünkü her bir defasında kadınların kendileri için çizilen sınırları aşmalarından, "randevu evi"nden akıl hastanesine ve sonunda ölüme uzanan bir çizgide karşılaşacakları tehlikelerden söz edilir. Bu örnekler Kraft-Ebbing'den başlayarak detaylı biçimde sınıflandırılan, örnek olaylar üzerinden anlatılan ve adlandırılarak psikiyatri içinde yerini bulan "sapkınlık" çeşitleridir ancak bir yandan ötekini arzulama biçimleri, başkalarının cinsel hayatını fantastik biçimde sunmanın bir yoluna dönüşür, öte yandan bu betimlemelerin yayının satışını artırma ihtimali yüksektir. Cinsellik alanında sınırları zorlayan kadınların bu yolda alışkanlık geliştirecekleri de yine bilimsel araştırmalara dayanıldığı iddiasıyla ve "iş ince ve ufaktan başlar" uyarısıyla açıklanır. Bu sapkınlıklar arasında "idrar yoluna kazara çeşitli şeyler sokulması" ve "sevicilik" de yer alır. İlkinin "gittikçe daha kalın ve uzun şeylere ihtiyaç" duymaya yol açacağı, ikincinin ise "erkekle cinsel ilişki yaşamış bir kadından hamile kalma” tehlikesi taşıdığı belirtilir.

\section{Sonuç yerine}

Freud, ${ }^{97}$ uygarlığı saldırganlık ve cinselliğin denetlenmesi üzerinde yükselen tedirgin bir varoluş olarak görüyordu; Elias, ${ }^{98}$ Batı Ortaçağ ve Rönesans dünyasının gündelik yaşam pratiklerini düzenlemeye talip olan görgü metinlerine bakarak, uygarlığı insan davranışlarının dönüşme biçimi olarak ele aldı. İnsanların bir aradayken yapmaları uygun görülmeyen davranışları anlatan bu metinler yığını Elias'a göre utanma ve sıkılma eşiğinin giderek yükselişine, özdenetimin artışına işaret ediyorlardı. Foucault ise, söylemin disipline edici pratiklerinden söz ederek davranışları biçimlendirmeye yönelik bu metinlerin çeşitliliğine işaret etti. Bu çalışmada sözü edilen metinler tıp, psikiyatri ve psikolojiden beslenen seksoloji söyleminin kurucusu niteliğindedir. Herkesin anlayabilmesi için yazılmış ancak kadınları kontrol etmeye yönelik metinlerdir. Disiplin söyleminin her yeri istila eden gücü sayesinde farklı metinler içinden geçerler. Metinlerarası ve söylemlerarası ilişkiler kurarlar. Bu kimi zaman gündelik yaşamın dilinde "dulun etekleri düşmandır” biçiminde tezahür eder, kimi zaman şair ve filozoflardan bağlamından kopartılarak alınmış özlü sözlere dönüşür ya da istatistiksel bir bilgi olarak sunulur. 


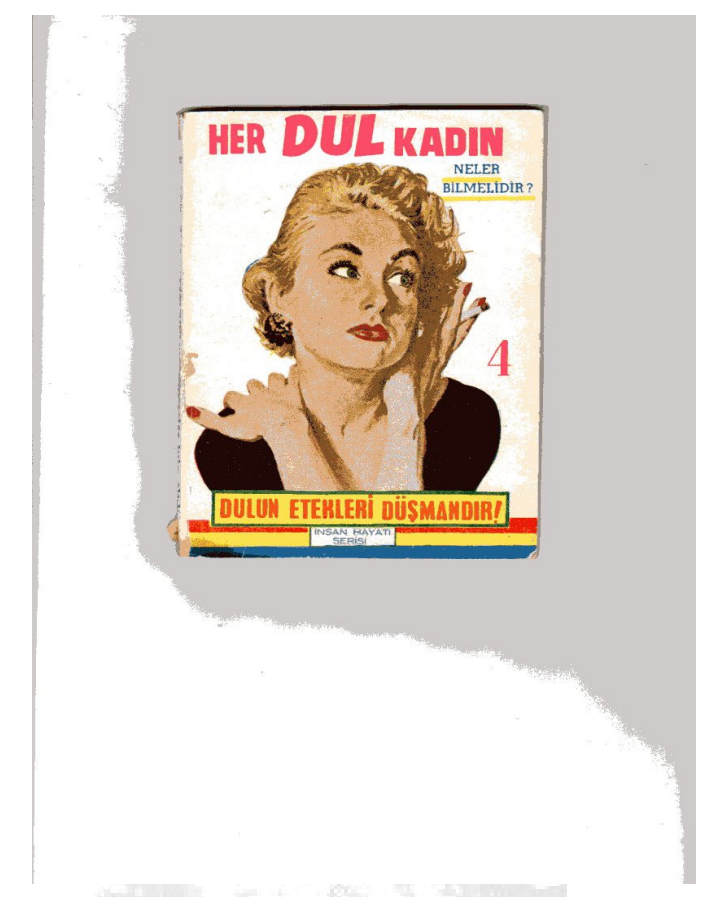

Ondokuzuncu yüzyılın buluşu olan seksoloji bugün varlığını kavramlarını daha "ehlileştirmiş" halde, cinsel sağlık araştırmaları, insan cinselliği, aile sağlığı gibi adlarla çeşitli kurumlarda, metinlerde ve politikalarda sürdürmektedir. Ancak antik dünyanın cinsellik kılavuzları, seksoloji metinleri ve kadınlara öğüt kitaplarının dili arasında çok büyük kopukluklar da yoktur, tersine izlenebilir bir süreklilik vardır. Cinsellik hepsinde sınıflama, yarar, fayda, üretkenlik ve hazzın artırılması üzerinden konu olurken kadın daima denetlenmesi, anlaşılması, zihni okunması ve eğitilmesi gerekendir. Hepsinde olacakların önceden bilindiği ve olması gerekenin anlatıldığı bir kadın yaşamı kurgulanmıştır. Seksoloji ile birlikte kurnazca önerilere, şiirlere, özlü sözlere, ahlak kurallarına bir de grafiğin gündelik yaşam pratiklerine indirgenemez görselliği eklenmiştir. Öte yandan çeviri, telif, eski ya da yeni olduğuna bakmaksızın tüm bu metinlerde kadın, rahim, mutfak, motor, zemberek, çoban, tarla ve millet terimleri ile simgeleştirilir. Burada kelimelerin metaforik kullanımları ya da metaforun doğası gereği taşıdığı gerilimlerden çıkarılabilecek yeni manalar artı önemsizleşir. Çünkü tüm bu betimlemeler el birliği ile içinde kadının yer almadığı bir uzama işaret ederler. Bu söylemde kadının kimi zaman saf, masum ve millet olarak nitelenmesi, kimi zaman da kötülük kaynağı olarak kurgulanması bir çelişkiye değil, doğrudan bilinmezliğe ve bilinmezlik kaynaklı tehdit ve uyarının şiddetini artırmaya yönelik bir stratejiye işaret eder. Kadın ilk önce kendi bilinmezliğinden korkmalıdır bu metinlere göre. Bilinmezlik vurgusu kitapların isimlerinden başlar: Evliliğin İlk Basamağında Neler Bilmelidir?, Kimseye Söyliyemem! Her Evli Kadın Neler Bilmelidir. Bu bilinmezlik, gizlililik, gizem dili içerisinde kadını bekleyen ve kadından kaynaklanan tehlikeler iç içe geçmiştir. Öte yandan yapması beklenen işler yığını içerisinde kadının varlığı, işaret eden ve edilen ilişsisinde fiziksel ya da nedensel olarak doğrudan bağlantılı kabul edilen doğal işaretler ya da medikal semptomlar gibi indeksli biçimde tahayyül edilir. Ateş ve duman arasında kurulan ilişki gibi kadının varlığına işaret eden de öncelikle karnı doymuş, cinsel tatmini bulmuş bir erkek, eşyaların temizliği, hijyen ve evin düzeni olacaktır. Bunların varlığı bir kadının varlığı demektir. 
${ }^{1}$ Ademoğlu, Hayatta Muaffak Olmak İçin Bir Kadının Bileceği Şeyler, (İstanbul: Tefeyyüz Kitaphanesi, 1932)12.

${ }^{2}$ Margery Wilson, Kadınlık Sanatt: Beğenilmek Elinizdedir, (İstanbul: Arif Bolat Kitabevi, 1949).

${ }^{3}$ Fikriye Sunuhi Arsan, Annelere ve Genç Kızlara Öğütler, (İstanbul: İnk1lâp Kitabevi, 1949).

${ }^{4}$ Roch Bess, Evli Kadınlar İçin Metres Tehlikesi, (İstanbul: Hadise Yayınevi, 1956).

${ }^{5}$ Daniş Remzi Korok, Genç Kızlara Göre İzdivaç ve Zifaf, (İstanbul: Bozkurt Basımevi,1937).

${ }^{6}$ Kemalettin Tuğcu, Dişi Kuş: Kocanızı Nasıl Muhafaza Edebilirsiniz, (İstanbul: Arif Bolat Kitabevi,1943).

${ }^{7}$ Vatsyayana, Kama Sutra, (Trans. Richard Burton, http://www.gutenberg.org/files/27827/27827-h/27827-h.htm).

${ }^{8}$ Ovid. Aşk Sanatı (İstanbul: İş Bankası Yayınları: 2010).

${ }^{9}$ Şeyh Nefzavi, Kokulu Bahçe (İstanbul: Başak Yayınevi, 1967).

${ }^{10}$ Şeyh Nefzavi, Kokulu Bahçe, 57.

${ }^{11}$ Murat Bardakçı, Osmanlı'da Seks: Sarayda Gece Dersleri, (İstanbul: Gür Yayınları, 1992), 49-50.

${ }^{12}$ Michel Foucault, Cinselliğin Tarihi, (İstanbul: ayrıntı Yayınları, 2007) 81.

${ }^{13}$ Foucault, Cinselliğin Tarihi, 48.

${ }^{14}$ Foucault, Cinselliğin Tarihi, 79-80.

${ }^{15}$ Richard Von Krafft-Ebing, Tenasül Hayatımızda Bozukluklar, (İstanbul: Arif Bolat Kitabevi,1949).

${ }^{16}$ Krafft-Ebing, Tenasül Hayatımızda Bozukluklar, 11.

${ }^{17}$ Aşsın tehlikeleri sadece seksoloji içinden dillendirilmiş bir konu değildir. 11 yüzyıl hukukçusu, dilbilimcisi ve edebiyatçısı olan Endülüslü İbn Hazm da aşk ve aşıklar üzerine yazdığı Güvercin Gerdanlığı kitabında aşkın yol açabileceği arazlardan, bunları uzman hekimlerin nassıl anladığından ve aşkın ölüme sebep olabileceğinden söz etmiş̧ir. İbn Hazm, Güvercin Gerdanlğğ: Sevgiye ve Sevenlere Dair, (İstanbul: İnsan Yayınları, 2000), $189-210$.

${ }^{18}$ Krafft-Ebing, Tenasül Hayatımızda Bozukluklar, 11 .

${ }^{19}$ Krafft-Ebing, Tenasül Hayatımızda Bozukluklar,65-66.

${ }^{20}$ Krafft-Ebing, Tenasül Hayatımızda Bozukluklar, 65.

${ }^{21}$ Ivan Crozier "Havelock Ellis, Eonism and the Patient's Discourse; or, Writing a Book about Sex", History of Psychiatry 11, No. 42, (2000), 125154.

${ }^{22}$ Cemal Zeki Önal, Evlilik ve Mahremiyetleri: Sevmek ve Sevilmek, Aşkin Fizyolojisi, (İstanbul: İnkılâp ve Aka Kitabevleri,1972).

${ }^{23}$ Önal, Evlilik ve Mahremiyetleri: Sevmek ve Sevilmek, Aşkın Fizyolojisi, 77.

${ }^{24}$ Önal, Evlilik ve Mahremiyetleri: Sevmek ve Sevilmek, Aşkın Fizyolojisi, 83.

${ }^{25}$ Theodoor Hendrik Van de Velde, Mükemmel İzdivaç, Fizyolojisi ve Tekniği, (İstanbul: Tecelli Basımevi, 1948).

${ }^{26}$ Van de Velde, Mükemmel İzdivaç, Fizyolojisi ve Tekniği, 241-245.

${ }^{27}$ Enoch Heinrich Kisch, The Sexual Life of Woman in its Physiological, Pathological and Hygienic Aspects, (New York: Rebman Company, 1910), 5.

${ }^{28}$ Krafft-Ebing, Tenasül Hayatımızda Bozukluklar, 18.

${ }^{29}$ Van de Velde, Mükemmel İzdivaç, Fizyolojisi ve Tekniği, 143-148.

${ }^{30}$ Lucy Bland ve Laura Doan Sexology in Culture: Labeling Bodies and Desires, (Chicago: University of Chiago Press, 1998).

${ }^{31}$ William James, Pragmacılık (İstanbul: Mili Eğitim Bakanlığı Yayınları, 1948).

${ }^{32}$ Rudolf Von Urban, Aşk Sanatı, (İstanbul: Seksoloji Yayınları, 1950).

${ }^{33}$ Seksoloji: Cinsi Bilgiler Mecmuasi 2, no.15, (1950): 24.

${ }^{34}$ Seksoloji: Cinsi Bilgiler Mecmuasi 4, no.40, (1952): 31.

35“"Dünyada Cinsi Hayat”, Seksoloji: Cinsi Bilgiler Mecmuası 4, no.39, (1952): 49-52.

36“"Dünyadan Cinsiyet Haberleri,” Seksoloji: Cinsi Bilgiler Mecmuası 5, no.50, (1953): 58.

${ }^{37}$ Seyfettin Asu, "Kore ve Japonya'da Cinsiyet ve Evlilik Hayatı" Seksoloji Cinsi Bilgiler Mecmuası 3, no.35, (1952): 22-26.

38،"Sual ve Cevaplar," Seksoloji: Cinsi Bilgiler Mecmuası 2, no.13, (1950): 64.

39“"Karılarını Niçin Severler?” Seksoloji: Cinsi Bilgiler Mecmuası 3, no. 25, (1951): 25-27.

${ }^{40}$ Dr. Philm, Seksoloji: Cinsi Bilgiler Mecmuast 5, no.55, (1953): 19-22.

41، "Dış Tesirler Altında Duygulanan Bakireler," Seksoloji ve Gençlik Hayatt: Genç kzzlğğn En Esrarlı Tarafi, Bakirelik, no1, (1959): 21.

${ }^{42}$ Enoch Heinrich Kisch, Kadn: Seksiel hayat ve Evlilige Sadakatsizlliği, (Ankara: Berkalp Kitabevi, 1944),44.

${ }^{43}$ Seksoloji ve Gençlik. Hayati: Genç kırlğğn En Esrarl Tarafi: Bakirelik, 22-27.

${ }^{44}$ Kisch, Kadın: Seksüel Hayatı ve Evliliğe Sadakatsizliği, 95.

${ }^{45}$ Kisch, Kadın: Seksüel Hayatı ve Evliliğe Sadakatsizliği, 95.

${ }^{46}$ Zeki Zeren, Bekârlık ve Evlilik Bilgisi ve Öğ̈̈tleri, (İstanbul: Kanaat Kitabevi, 1940), 12.

${ }^{47}$ Kisch, Kadın: Seksüel Hayatı ve Evliliğe Sadakatsizliği, 96-97.

${ }^{48}$ Kisch, Kadın: Seksüel Hayatı ve Evliliğe Sadakatsizliği, 96.

${ }^{49}$ Zeren, Bekârllk. ve Evlilik. Bilgisi ve Ögütleri, 12-13.

${ }^{50}$ Hilmi Malik, Annelerin Kızlarına Öğütleri, (Ankara: Ankara Halkevi Neşriyatı, 1933).

${ }^{51}$ Tuğcu, Dişi Kuş: Kocanızı Nasıl Muhafaza Edebilirsiniz, 29.

${ }^{52}$ Tuğcu, Diși Kuș: Kocamı̨ Nasll Mubafaza Edebilirsiniz,29-30.

${ }^{53}$ Afsaneh Najmabadi, “Sevgili ve ana Olarak Erotik Vatan: Sevmek, Sahiplenmek, Korumak”, Vatan Millet-Kadinlar, Der. Ayşe Gül Altınay, (İstanbul: İletişim Yayınları, 2004), 129-167.

${ }^{54}$ Ademoğlu, Hayatta Muaffak Olmaki Ị̇in Bir Kadmm Bileceği Șeyler, 9.

${ }^{55}$ Ademoğlu, Hayatta Muaffake Olmak Ị̇in Bir Kadmmn Bileceğ̈i Seyler, 238.

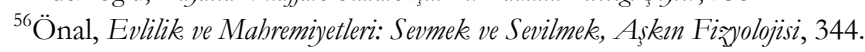

${ }^{57}$ Kemalettin Tuğcu, Hayat Arkadaşs: İyi Bir Koca Nasil Bulunur, (İstanbul: Arif Bolat Kitabevi, 1943), 55.

${ }^{58}$ Tuğcu, Hayat Arkadaşs: İyi Bir Koca Nasll Bulunur, 51. 
${ }^{59}$ Holliday , Kimseye Söyliyemem: Her Evli Kadın Neler Bilmelidir, (İstanbul: Hadise Yayınevi, 1956),13.

${ }^{60}$ Arsan, Annelere ve Genç Kızlara Öğütler, 68.

${ }^{61}$ Wilson, Kadınlık Sanatı: Beğenilmek Elinizdedir, 213.

${ }^{62}$ Holliday , Kimseye Söyliyemem: Her Evli Kadın Neler Bilmelidir, 23.

${ }^{63}$ Arsan, Annelere ve Genç Kızlara Öğ̈̈tler, 41.

${ }^{64}$ Arsan, Annelere ve Genç Kızlara Öğ̈ütler, 45.

${ }^{65}$ Arsan, Annelere ve Genç Kızlara Öğ̈̈tler, 36.

${ }^{66}$ Michel de Certeau, Gündelik Hayatın Keşfi-1: Eylem, Uygulama, Üretim Sanatları (Ankara: Dost Kitabevi, 2009).

${ }^{67}$ Arsan, Annelere ve Genç Kızlara Öğ̈̈tler, 93.

${ }^{68}$ Kisch, Kadın: Seksüel Hayatı ve Evliliğe Sadakatsizliği, 9.

${ }^{69}$ Elias Canetti, Kitle ve İktidar, (İstanbul: Ayrıntı Yayınları, Canetti, 1998), 288-290.

${ }^{70}$ Korok, Genç Kızlara Göre İdivaç ve Zifaf, 3.

${ }^{71}$ Wilson, Kadınlık Sanatı: Beğenilmek Elinizdedir, 21-80.

${ }^{72}$ Âdemoğlu, Hayatta Muvaffak olmak için Bir kadını Bileceği Şeyler, 17.

${ }^{73}$ Arsan, Annelere ve Genç Kızlara Öğütler, 68.

${ }^{74}$ Arsan, Annelere ve Genç Kızlara Öğ̈ütler, 68.

${ }^{75}$ Tuğcu, Dişi Kuş: Kocanızı Nasıl Muhafaza Edebilirsiniz, 66-67.

${ }^{76}$ Önal, Evlilik ve Mahremiyetleri: Sevmek ve Sevilmek, Aşkın Fizyolojisi, 77.

${ }^{77}$ Tuğcu, Dişi Kuş: Kocanızı Nasıl Muhafaza Edebilirsiniz, 69.

${ }^{78}$ Krafft-Ebing, Tenasül Hayatımızda Bozukluklar, 22.

${ }^{79}$ Ademoğlu, Hayatta Muvaffak olmak için Bir kadını Bileceği Şeyler, 17-18.

${ }^{80}$ Bess, Evli Kadınlar İçin Metres Tehlikesi, 15-21.

${ }^{81}$ Bess, Evli Kadınlar İçin Metres Tehlikesi, 4.

${ }^{82}$ Tuğcu, Dişi Kuş: Kocanızı Nasıl Muhafaza Edebilirsiniz, 89-90.

${ }^{83}$ Arsan, Annelere ve Genç Kızlara Öğ̈̈tler, 74.

${ }^{84}$ Tuğcu, Dişi Kuş: Kocanızı Nasıl Muhafaza Edebilirsiniz, 73-74.

Tüm bu metinler yığını arasında Kemâlettin Tuğcu'nun ayrı bir yeri vardır. Yazarın burada sözü edilmeyen çocuk kitapları Türkiye'de uzun yıllar boyunca eğitim kurumlarında okutulması önerilenler arasında yer almıştır. Sayısı iki yüzü bulan Tuğcu romanlarında, iyi, kötü, öksüz, yetim, anne ve babası olan, sokakta ya da sığındığı insanların yanında yaşamak zorunda kalan, köylü, şehirli, bedensel engelli, balıkçı, gazeteci, küçük bey ya da küçük hanım, bütün çocuklar mutlu sona ulaşabilmek için ağır koşullarda test edilirken her birine ilişkin bedensel tahayyüller devreye girer. Zengin, şişman, fettan, sarışın, dikiş dikebilen, elinden iş gelen, obur, hırsız ya da şükretmeyi bilen kız ve erkek çocuklar hep bedenleri üzerinden imlenirler. Bu bağlamda uzun yıllar bu çocukların imgeleri ile yetişmiş kuşaklar için Tuğcu'nun bu iki kitabında kadınlara verdiği öğütler çok kolaylıkla anlaşılabilir ve içselleştirilebilir cinstendir. Bu konuda bir çalışma için bkz., Aslı Yazıcı Yakın. "Çeşme Sokağının Kayıp Çocukları: Kemâlettin Tuğcu Romanları ve Disiplin”, Kebikeç: Insan Bilimleri için Kaynak Araştırmaları Dergisi, 19 (2005):189-209.

${ }^{85}$ Michel Foucault, Cinselliğin Taribi, 144.

${ }^{86}$ Holliday, Kimseye Söyliyemem: Her Evli Kadın Neler Bilmelidir, 16.

${ }^{87}$ Fernande Isambert, Evliliğin İlk Basamă̆ında Neler Bilmelidir?, (İstanbul: Hadise Yayınevi, 1956), 11.

${ }^{88}$ William J. Fielding, ve Edwin Hirchi Evlilikte İlk Gece ve Zifaf Adedleri, (İstanbul: Renk Yayınevi, 1964), 7-11.

${ }^{89}$ Holliday , Kimseye Söyliyemem: Her Evli Kadın Neler Bilmelidir, 90-91.

${ }^{90}$ Kisch, Kadın: Seksüel hayatı ve Evliliğe Sadakatsizliği, 77.

${ }^{91}$ Kisch, Kadın: Seksüel hayatı ve Evliliğe Sadakatsizliği, 73.

${ }^{92}$ Betty Whiting, Her Dul Kadın Neler Bilmelidir, (İstanbul: Hadise Yayınevi, 1956), 31.

${ }^{93}$ Kisch, Kadın: Seksüel hayatı ve Evliliğe Sadakatsizliği, 97.

${ }^{94}$ Kisch, Kadın: Seksüel hayat ve Evliliğe Sadakatsizliği, 35.

${ }^{95}$ Kisch, Kadın: Seksüel hayat ve Evliliğe Sadakatsiz̨liği, 37.

${ }^{96}$ Kisch, Kadin: Seksüel hayatı ve Evlilĭge Sadakatsizliği, 38.

${ }^{97}$ Sigmund Freud, Uygarlı̆̆ın Huzursuzluğu (İstanbul: Metis Yayınları, 1999).

${ }^{98}$ Norbert Elias, Uygarlaşma Süreci: Sosyo- Oluşumsal ve Psiko- Oluşumsal İncelemeler, Cilt I, (İstanbul: İletişim Yayınları, 2000). 


\section{Kaynakça}

Ademoğlu. Hayatta Muaffak Olmak İçin Bir Kadının Bileceği Şeyler (İstanbul: Tefeyyüz Kitaphanesi, 1933).

Akbeğ, Faruk. "Yabancı Memleketlerde Cinsi Hayat" Seksoloji Cinsi Bilgiler Mecmuası 3, no.35, (1952): 10-13.

Asu,Seyfettin . "Kore ve Japonya'da Cinsiyet ve Evlilik Hayatı" Seksoloji Cinsi Bilgiler Mecmuası 3, no.35, (1952): $22-$ 26.

Arsan, Fikriye Sunuhi. Annelere ve Genç Kızlara Öğ̈̈tler (İstanbul:İnk1lâp Kitabevi, 1949).

Bess, Roch. Evli Kadınlar İçin Metres Tehlikesi (İstanbul: Hadise Yayınevi,1956).

Bland, Lucy \&Laura Doan. Sexology in Culture: Labeling Bodies and Desires (Chicago: University of Chiago Press, 1998).

Canetti, Elias. Kitle ve İktidar (İstanbul: Ayrıntı Yayınları, 1998).

Crozier, Ivan. "Havelock Ellis, Eonism and the Patient's Discourse;or, Writing a Book about Sex", History of Psychiatry 11, No. 42, (2000), 125-154.

de Certeau, Michel. Gündelik Hayatın Keşfi-1: Eylem, Uygulama, Üretim Sanatları (Ankara: Dost Kitabevi, 2009).

Elias, Norbert. Uygarlaşma Süreci (İstanbul: İletişim Yayınları, 2000).

Fielding, William J. Ve Hirch, Edwin W. Evlilikte İlk Gece ve Zifaf Adedleri (İstanbul: Renk Yayınevi, 1964).

Foucault, Michel. Cinselliğin Tarihi, Cilt I-II, (İstanbul: Afa Yayınları, 1988).

Freud, Sigmund. Uygarlı̆̆ın Huzursuzluğu, (İstanbul: Metis Yayınları, 1999).

Holliday. Kimseye Söyliyemem: Her Evli Kadın Neler Bilmelidir (İstanbul: Hadise Yayınevi, 1956).

Isambert, Fernande. Evliliğin İlk Basamă̆ında Neler Bilmelidir? (İstanbul: Hadise Yayınevi, 1956).

James, William. Pragmacılık (İstanbul: Mili Eğitim Bakanlığı Yayınları, 1948).

Kisch, Enoch Heinrich. The Sexual Life of Woman in its Physiological, Pathological and Hygienic Aspects (New York: Rebman Company, 1910).

Kisch, Enoch Heinrich. Kadın: Seksüel hayatı ve Evliliğe Sadakatsizliği (Ankara: Berkalp Kitabevi, 1944).

Korok, Daniş Remzi. Genç Evli Kadınlarla Gizli Konuşmalar (İstanbul: Sebat Basımevi, 1936).

Korok, Daniş Remzi. Genç Kızlara Göre İzdivaç ve Zifaf (İstanbul: Bozkurt Basımevi, 1937).

Korok, Daniş Remzi. Evli Kadınlara Göre Memnu Meyve (İstanbul: Numune Matbaası, 1937).

Korok, Daniş Remzi Genç Kızlarda Fena adetler: Istişha ve Zürefalık (İstanbul: Numune Matbaası, 1937).

Korok, Daniş Remzi. Dul Kadınlara Rağbet ve Sebepleri (İstanbul Bozkurt Basımevi, 1937).

Krafft-Ebing. Tenasül Hayatımızda Bozukluklar, (İstanbul: Arif Bolat Kitabevi, 1949).

Malik, Hilmi. Annelerin Kızlarına Öğ̈̈̈tleri (Ankara: Ankara Halkevi Neşriyatı, 1933).

Najmabadi, Afsaneh. "Sevgili ve ana Olarak Erotik Vatan: Sevmek, Sahiplenmek, Korumak", Vatan -Millet- Kadınlar, Der. Ayşe Gül Altınay, (İstanbul: İletişim Yayınları, 2004), 129-167.

Ovidius. Aşk Sanatı (İstanbul: İş Bankası Yayınları: 2010).

Önal, Cemal Zeki. Evlilik ve Mahremiyetleri: Sevmek ve Sevilmek, Aşkın Fizyolojisi, 7. Baskı (İstanbul: İnkılap ve Aka Kitabevleri, 1972). 
Peirce, Charles Sanders The Essential Peirce. Vol. 2. Ed.. Peirceedition Project. (Bloomington I.N.: Indiana University Press, 1998).

Ricoeur, Paul. Yorum Teorisi: Söylem ve Artı Anlam (İstanbul: Paradigma Yayıncılık, 2007).

Seksoloji: Cinsi Bilgiler Mecmuası 2, no.15, (1950).

Seksoloji: Cinsi Bilgiler Mecmuası 4, no.40, (1952).

Seksoloji: Cinsi Bilgiler Mecmuası 4, "Sual ve Cevaplar," no.39, (1952).

Seksoloji: Cinsi Bilgiler Mecmuası 2, no.13, (1950).

Tuğcu, Kemâlettin. Hayat Arkadaşı: İyi Bir Koca Nasıl Bulunur (İstanbul: Arif Bolat Kitabevi, 1943).

Tuğcu, Kemâlettin. Dişi Kuş: Kocanızı Nasıl Muhafaza Edebilirsiniz (İstanbul: Arif Bolat Kitabevi, 1943).

Van de Velde, Hendrik. Mükemmel İzdivaç, Fizyolojisi ve Tekniği (İstanbul: Tecelli Basımevi, 1948).

Von Urban, Rudolf . Aşk Sanatı, (İstanbul: Seksoloji Yayınları, 1950).

Whiting, Betty. Her Dul Kadın Neler Bilmelidir (İstanbul: HadiseYayınevi, 1956).

Yazıcı Yakın, Aslı. "Çeşme Sokağının Kayıp Çocukları: Kemalettin Tuğcu Romanları ve Disiplin", Kebikeç: İnsan Bilimleri için Kaynak Araştırmaları Dergisi,19 (2005):189-209.

Yolaç, Hilmi. İdeal Kadın: Ev İşleri, Ekonomi ve Teknolojisi (İstanbul: Marifet Basımevi,1946).

Zeren, Zeki. Bekârlık ve Evlilik Bilgisi ve Öğ̈̈tleri (İstanbul: Kanaat Kitabevi, 1940). 